\title{
Levels of Cocaine- and Amphetamine-Regulated Transcript in Vagal Afferents in the Mouse Are Unaltered in Response to Metabolic Challenges
}

\author{
(D) Xuefeng Yuan, ${ }^{1,2}$ Ying Huang, ${ }^{1}$ (D) Sarita Shah, ${ }^{1}$ Hua $\mathrm{Wu}^{2}{ }^{2}$ and ${ }^{\circ}$ Laurent Gautron ${ }^{1}$
}

DOI:http://dx.doi.org/10.1523/ENEURO.0174-16.2016

${ }^{1}$ Division of Hypothalamic Research and Department of Internal Medicine, The University of Texas Southwestern Medical Center, 5323 Harry Hines Blvd., Dallas, Texas 75390, ²Department of Orthopedics, Tongji Hospital, Tongji Medical College, Huazhong University of Science and Technology, Wuhan, China

\section{Visual Overview}

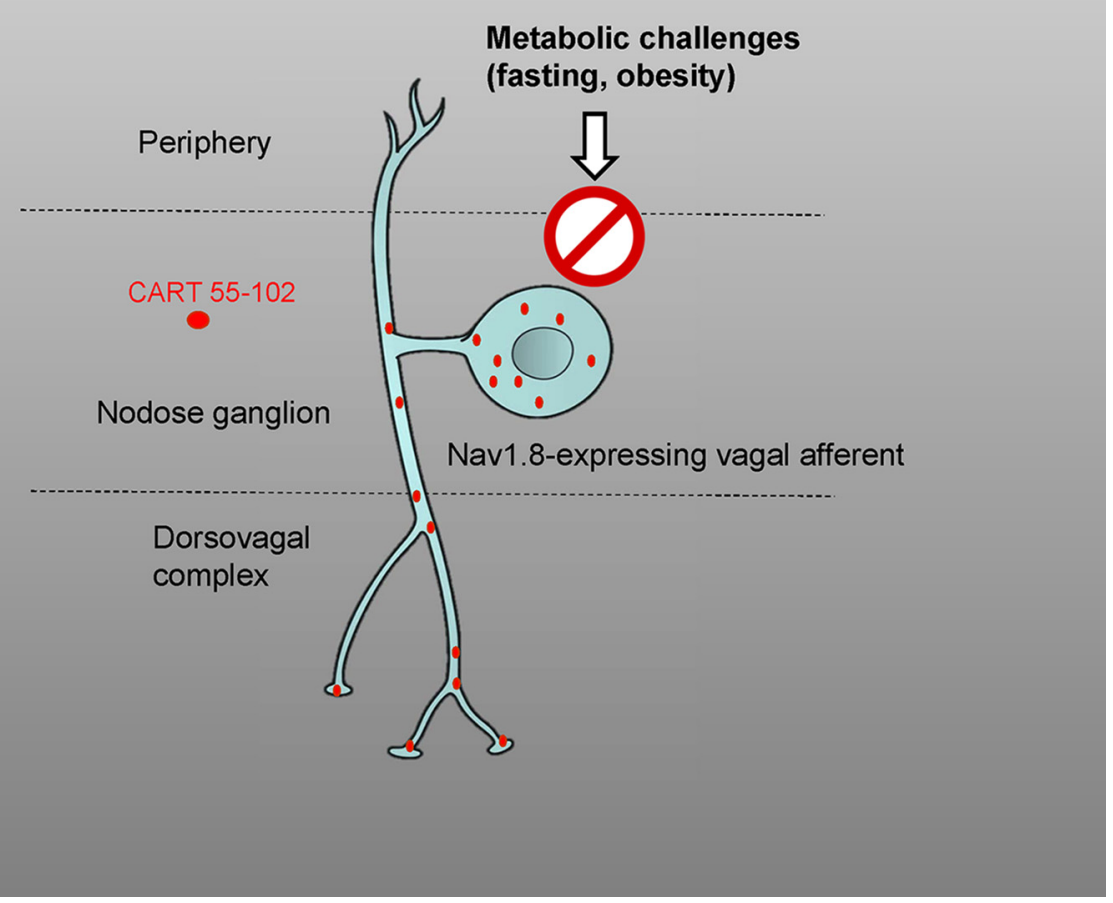

Cocaine- and amphetamineregulated transcript (CART) is one of the most abundant neuropeptides in vagal afferents, including those involved in regulating feeding. Recent observations indicate that metabolic challenges dramatically alter the neuropeptidergic profile of CARTproducing vagal afferents. Here, using confocal microscopy, we reassessed the distribution and regulation of CART(55-102) immunoreactivity in vagal afferents of the male mouse in response to metabolic challenges, including fasting and high-fatdiet feeding. Importantly, the perikarya and axons of vagal C-fibers were labeled using mice expressing channelrodhopsin-2 (ChR2-YFP) in $\mathrm{Na}_{v} 1.8$-Cre-expressing neurons. In these mice, approximately $82 \%$ of the nodose

\section{Significance Statement}

Recent studies reported that fasting triggers vagal afferents to switch from expressing anorectic to orexigenic neuropeptides. This study failed to replicate those observations using a combination of confocal microscopy, immunohistochemistry, and in situ hybridization. In particular, we showed that neither fasting nor diet-induced obesity influences immunoreactivity for cocaine- and amphetamine-regulated transcript neuropeptide in mouse vagal afferents. In contrast to previous studies, we also failed to detect melanin-concentrating hormone expression in mouse vagal afferents. Overall, we reached the conclusion that the neuropeptidergic profile of the vagal afferents involved in feeding is remarkably stable in response to metabolic challenges. 
ganglion neurons were labeled with ChR2-YFP. Furthermore, ChR2-YFP-labeled axons could easily be identified in the dorsovagal complex. CART(55-102) immunoreactivity was observed in 55\% of the ChR2-YFP-labeled neurons in the nodose ganglion and $22 \%$ of the ChR2-YFP-labeled varicosities within the area postrema of fed, fasted, and obese mice. The distribution of positive profiles was also identical across the full range of CART staining in fed, fasted, and obese mice. In contrast to previous studies, fasting did not induce melaninconcentrating hormone $(\mathrm{MCH})$ immunoreactivity in vagal afferents. Moreover, prepro-MCH mRNA was undetectable in the nodose ganglion of fasted mice. In summary, this study showed that the perikarya and central terminals of vagal afferents are invariably enriched in CART and devoid of $\mathrm{MCH}$.

Key words: immunohistochemistry; metabolism; neuropeptide; vagus nerve

\section{Introduction}

More than 16 years ago, Broberger et al. (1999) showed that cocaine- and amphetamine-regulated transcript (CART) was expressed in half of vagal afferents, making it one of the most abundantly expressed neuropeptides in the nodose ganglion. Different CART peptides can be generated by splicing and enzymatic cleavage of a precursor peptide in a tissue-specific manner (Koylu et al., 1997; Thim et al., 1999). The long form of CART is highly expressed in the hypothalamus and is considered to be one of the most biologically active CART peptides, with proven anorectic actions (Stanley et al., 2001). In the past, CART expression in the nodose ganglion was detected mainly using antibodies raised against the long form of CART (Broberger et al., 1999; Zheng et al., 2002).

Recent pharmacological and RNA interference experiments suggested that vagally released CART was implicated in the anorectic actions of cholecystokinin (CCK) (De Lartigue et al., 2010; Heldsinger et al., 2012). Most CART-containing vagal afferents were shown to coexpress CCK receptor (Broberger et al., 1999), further ascertaining the role of vagally released CART in feeding. In addition, one retrograde tracing study showed that many CART-positive vagal afferents project to the rat duodenum and stomach (Zheng et al., 2002). Inconsistent observations have also been reported regarding the anorectic actions of CART in the brain (Rogge et al.,

Received June 22, 2016; accepted September 16, 2016; First published September 22, 2016.

The authors declare no competing financial interests

Author Contributions: $\mathrm{XY}, \mathrm{YH}$, and SS performed research; HW analyzed data; LG performed research, analyzed data, and wrote the paper.

This work was supported by the American Neurogastroenterology and Motility Society Research Grant (2013-2014). The research reported in this publication was also supported by the National Center for Advancing Translational Sciences of the National Institutes of Health under award \#UL1TR001105.

Acknowledgments: We are grateful to the members of the UT Southwestern Live Cell Core Facility. We thank Dr. John Wood (University College London) for providing $\mathrm{Na}_{\mathrm{v}} 1.8-\mathrm{Cre}$ mice. We thank Dr. William Holland and Trevor Tippetts (both at UT Southwestern Touchstone Diabetes Center) for giving us rats. We thank Dr. Pierre-Yves Risold (Université de Franche-Comté) for his input on the murine $\mathrm{MCH}$ system. We are also grateful to Solène and Syann Lee for editing our cover letter.

Correspondence should be addressed to Laurent Gautron, 5323 Harry Hines Blvd., Dallas, TX 75390. E-mail: laurent.gautron@UTSouthwestern.edu

DOI:http://dx.doi.org/10.1523/ENEURO.0174-16.2016

Copyright (C) 2016 Yuan et al.

This is an open-access article distributed under the terms of the Creative Commons Attribution 4.0 International, which permits unrestricted use, distribution and reproduction in any medium provided that the original work is properly attributed.
2008). In particular, administration of CART in the fourth ventricle suppressed feeding (Aja et al., 2002), and CART microinjection into areas of the nucleus of the solitary tract supplied by CART-positive afferents was ineffective at suppressing feeding (Zheng et al., 2002). Hence, the role of vagally released CART in feeding is controversial. In addition, CART regulation in vagal afferents in response to metabolic challenges remains confusing. One initial study reported that the percentage of rat nodose ganglion cells expressing CART mRNA remained unchanged after food restriction or diet-induced obesity (Broberger et al., 1999). Arguing against these results, several studies reported profound alterations in the neuropeptidergic profile of CART-positive afferents upon fasting. Specifically, fasting and leptin receptor deficiency in vagal neurons were shown to suppress CART immunoreactivity in rat and mouse nodose ganglia (de Lartigue et al., 2007, 2010,2014; de La Serre et al., 2015). Furthermore, the orexigenic peptide melanin-concentrating hormone $(\mathrm{MCH})$ was shown to be induced in the vagal afferents of fasted rats and mice that expressed CART in the fed condition (Burdyga et al., 2006; de Lartigue et al., 2007, 2014; de La Serre et al., 2015). To our knowledge, such a unique feeding-dependent switch in the neuropeptidergic profile of vagal afferents had never been reported before.

Given the aforementioned discrepancies and gaps in the literature, the first goal of this study was to reexamine CART(55-102) immunoreactivity in the cell body and axons of vagal $\mathrm{C}$-fibers in mice submitted to different metabolic challenges. We used transgenic mice in which $\mathrm{Na}_{\mathrm{v}} 1.8$-expressing neurons are labeled with channelrhodopsin-2 (ChR2) fused with yellow fluorescent protein (YFP) ( $\mathrm{Na}_{\mathrm{v}} 1.8-\mathrm{Cre}-\mathrm{ChR} 2-\mathrm{YFP}$ mice) to identify vagal $\mathrm{C}$-fibers. The second goal of this study was to characterize $\mathrm{Na}_{\mathrm{v}} 1.8-\mathrm{Cre}-\mathrm{ChR} 2-\mathrm{YFP}$ mice as a useful model to label vagal $\mathrm{C}$-fibers. $\mathrm{Na}_{\mathrm{v}} 1.8$-expressing peripheral afferents include all of the C-type peripheral afferents, as well as those expressing neuropeptides (Chiu et al., 2014; Usoskin et al., 2015). ChR2-YFP was chosen as a fluorescent reporter because of the emerging evidence of its usefulness in neuronal tract tracing studies (Jennings and Stuber, 2014). Unexpectedly, the present study showed that CART(55-102) present in the perikarya and central terminal of the vagal $\mathrm{C}$-fibers was not regulated by metabolic challenges. In contrast to previous studies, we showed that CART-positive afferents in the mouse never produced $\mathrm{MCH}$. 


\section{Materials and Methods}

\section{Generation of animals and experimental groups}

$\mathrm{Na}_{\mathrm{v}}$ 1.8-Cre-ChR2-YFP mice were generated by crossing $\mathrm{Na}_{\mathrm{v}} 1.8-\mathrm{Cre}$ mice [Scn10atm2(cre)Jnw], which were kindly provided to us by Dr. Wood (Stirling et al., 2005), with Ai32 mice [Ai32(RCL-ChR2(H134R)/EYFP] expressing ChR2-YFP in a Cre-dependent manner. The Ai32 mice were originally designed by the Allen Institute (Madisen et al., 2010) and are currently available from the Jackson Laboratory (stock no. 012569; Bar Harbor, ME). The mice were all adult males (ages varying between 6 and 16 weeks of age) carrying one copy of $\mathrm{Na}_{v} 1.8-\mathrm{Cre}$ and one copy of ChR2-YFP. $\mathrm{Na}_{\mathrm{v}} 1.8-\mathrm{Cre}$ mice are useful for selectively inducing the expression of fluorescent proteins in $\mathrm{C}$-fiber neurons, including those in the vagus nerve. The usefulness of Ai32 mice in optogenetic and tracing experiments is also well documented (Daou et al., 2013; Muñoz et al., 2014).

The experimental animals were housed in a barrier facility in a temperature-controlled environment (lights on from 0600 to 1800) with ad libitum access to water and standard chow with $12 \%$ of calories from fat. All animal procedures were performed in accordance with the guidelines of our Institutional Animal Care and Use Committee at the University of Texas Southwestern Medical Center. For the metabolic challenges studies, we used 22 $\mathrm{Na}_{\mathrm{v}}$ 1.8-Cre-ChR2-YFP mice, which were divided into three groups consisting of animals fed chow ad libitum at all times (24.7 $\pm 0.9 \mathrm{~g}$ body weight, $n=7)$, animals fasted 16-24 $\mathrm{h}$ before sacrifice $(21.8 \pm 1.2 \mathrm{~g}$ body weight, $n=$ 7 ), and animals fed a high-fat diet (62\% calories from fat; Research Diet D12492i) for 4 weeks before sacrifice (35.0 $\pm 2.4 \mathrm{~g}$ body weight, $n=8$ ). A separate group of $\mathrm{Na}_{\mathrm{v}} 1.8-$ Cre-ChR2-YFP mice that were fed on chow ad libitum was used for the initial characterization of ChR2-YFP expression in the nodose ganglia and brains $(n=4)$, and a group of $\mathrm{Na}_{\mathrm{v}} 1.8-\mathrm{Cre}-\mathrm{ChR2-YFP}$ mice was used to map the peripheral organs $(n=4)$.

Eight C56/Bl6 male mice (6 weeks of age) divided into fed and fasted groups were also used for performing in situ hybridization (ISH). These mice were purchased from our institution animal husbandry and housed in the same barrier facility and environment as the $\mathrm{Na}_{\mathrm{v}} 1.8-\mathrm{Cre}-\mathrm{ChR} 2-$ YFP mice. Immunostaining was also performed in the nodose ganglia of six lean Zucker male rats $(6$ months of age) that were given to us by another laboratory on our campus. Rats were housed in a conventional facility in a temperature-controlled environment with ad libitum access to water and standard chow. Three rats were fed chow ad libitum at all times, and three were fasted $16 \mathrm{~h}$ before sacrifice.

\section{Tissue collection and preparation for immunohistochemistry}

On the day of sacrifice, between 0900 and 1100, the animals received an overdose of chloral hydrate (500 $\mathrm{mg} / \mathrm{kg}$, i.p.) and were then perfused transcardially with $0.9 \%$ saline followed by $10 \%$ formalin (Sigma, St. Louis, $\mathrm{MO}$ ) for $2 \mathrm{~min}$. Tissues, including the left nodose ganglion, were rapidly removed with the help of a dissecting scope and postfixed for approximately $1 \mathrm{~h}$. The nodose ganglion, brain, stomach wall, and duodenum were submerged in $20 \%$ sucrose overnight at $4^{\circ} \mathrm{C}$. The stomach muscularis was prepared as whole mounts for immediate immunostaining. Cryoprotected brains were sectioned at $25 \mu \mathrm{m}$ using a freezing microtome (1:5 series). The brain sections were collected in $0.1 \mathrm{M} \mathrm{PBS}(\mathrm{pH} 7.4)$, transferred in a cryoprotectant solution (30\% sucrose, $30 \%$ ethylene glycol), and stored at $-20^{\circ} \mathrm{C}$. Other cryoprotected tissues were frozen in TissueTek optimum cutting temperature compound (Sakura) on dry ice before being sectioned at $16 \mu \mathrm{m}$ using a cryostat (1:5 series). The sections were collected on SuperFrost slides and stored at $-80^{\circ} \mathrm{C}$.

\section{Antibody characterization}

Table 1 compiles the primary and secondary antibodies used in this study. A discussion of the specificity of our primary antibodies is listed below. All of them were commercially available.

\section{Polyclonal rabbit antibody against CART(55-102) (RRID: AB_2313614)}

We used the residue nomenclature established for rat CART peptides (Rogge et al., 2008). This antiserum was extensively characterized in the central nervous system and peripheral ganglia, including the nodose ganglion (Zheng et al., 2002; Valera et al., 2006; Gonsalvez et al., 2010; Reeber and Sillitoe, 2011). Controls for specificity included preadsorption with a CART(55-102) peptide and omission of the primary antibody (Dun et al., 2000; Reeber and Sillitoe, 2011). According to the manufacturer, this antibody detects a 5-kDa band on Western blot of rat brain samples. CART staining in both the brain and nodose ganglion samples displayed a distribution pattern that perfectly agreed with previous reports using this antiserum. The neurons in the nodose ganglion were not stained when the primary antibody was omitted.

\section{Antibody against CART(1-39)}

We also tested an antibody against CART(1-39) (cat. no. H-003-63; Phoenix Pharmaceuticals, Burlingame, CA; cat. no. AF163; R\&D Systems, Minneapolis, MN). However, this antibody failed to label the nodose ganglion and thus we have not included these data in the article. This is not completely surprising, since $\mathrm{H}-003-063$ was raised against a CART fragment that is not very well studied and is not considered as biologically relevant as CART(55102)

\section{Chicken anti-GFP polyclonal antiserum}

Many laboratories have used this antibody to label the mouse brain and ganglia of transgenic mice that express GFP and verified the absence of staining when it was used against wild-type tissue (Volkmann et al., 2010; Marques-Lopes et al., 2014). In addition, GFP-expressing hippocampal neurons showed endogenous fluorescence that was enhanced only by immunostaining with the antiserum (Yi et al., 2015).

\section{Peripherin polyclonal antiserum}

According to the manufacturer, this antiserum is regularly tested on PC12 lysates and detects a major band at $57 \mathrm{kDa}$. Lysates from cell lines transfected with the pe- 
Table 1. Information relative to the primary and secondary antisera used in the study.

\begin{tabular}{|c|c|c|c|c|c|c|}
\hline $\begin{array}{l}\text { Antibody } \\
\text { Primary antibody }\end{array}$ & Manufacturer & Catalog no. & Lot no. & Host & Working dilution & Immunogen \\
\hline Peripherin & EMD Millipore & AB1530 & 2446692 & Rabbit & $1: 500$ & $\begin{array}{l}\text { trp-E-peripherin fusion protein containing all but the four } \\
\mathrm{N} \text {-terminal amino acids of rat peripherin }\end{array}$ \\
\hline CART(55-102) & $\begin{array}{l}\text { Phoenix } \\
\text { Pharmaceuticals }\end{array}$ & $\mathrm{H}-003-62$ & $\begin{array}{r}01251-10 \\
01251-6\end{array}$ & Rabbit & $1: 800-1: 1000$ & $\begin{array}{l}\text { Ile-Pro-Ile-Tyr-Glu-Lys-Lys-Tyr -Gly-Gln-Val-Pro-Met-Cys-Asp- } \\
\text { Ala-Gly-Glu-Gln-Cys-Ala-Val-Arg-Lys-Gly-Ala-Arg-Ile-Gly-Lys-Leu-Cys- } \\
\text { Asp-Cys-Pro-Arg-Gly-Thr-Ser-Cys-Asn-Ser-Phe-Leu-Leu-Lys-Cys-Leu } \\
\text { [disulfide bonds between Cys1-Cys3,Cys2-Cys5,Cys4-Cys6] }\end{array}$ \\
\hline CART 1-39 & $\begin{array}{l}\text { Phoenix } \\
\text { Pharmaceuticals }\end{array}$ & $\mathrm{H}-003-63$ & 01102 & Rabbit & $1: 800-1: 1000$ & $\begin{array}{l}\text { pGlu-Glu-Asp-Ala-Glu-Leu-Gln-Pro-Arg-Ala-Leu-Asp-Ile-Tyr- } \\
\text { Ser-Ala-Val-Asp-Asp-Ala-Ser-His-Glu-Lys-Glu-Leu-Pro-Arg- } \\
\text { Arg-Gln-Leu-Arg-Ala-Pro-Gly-Ala-Val-Leu-Gln }\end{array}$ \\
\hline $\mathrm{MCH}$ & $\begin{array}{l}\text { Phoenix } \\
\text { Pharmaceuticals }\end{array}$ & $\mathrm{H}-070-47$ & 01629-3 & Rabbit & $1: 1000$ & $\begin{array}{l}\text { Asp-Phe-Asp-Met-Leu-Arg-Cys-Met-Leu-Gly-Arg-Val- } \\
\text { Tyr-Arg-Pro-Cys-Trp- Gln-Val }\end{array}$ \\
\hline $\mathrm{TH}$ & Abcam & ab101853 & GR120879-17 & Goat & $1: 1000$ & Synthetic peptide corresponding to human $\mathrm{TH}(30-100)$ ( $\mathrm{N}$ terminal) \\
\hline ProMCH & $\begin{array}{l}\text { Santa Cruz } \\
\text { Biotechnology }\end{array}$ & sc-14509 & B2415 & Goat & $1: 100-1: 1000$ & $\begin{array}{l}\text { 20-amino-acid peptide near the } \mathrm{C} \text {-terminus of } \\
\text { pro-MCH precursor of human origin }\end{array}$ \\
\hline $\begin{array}{l}\text { GFP } \\
\text { Secondary } \\
\text { antibody }\end{array}$ & Aves Laboratory & GFP-10120 & GFP697986 & Chicken & $1: 1000$ & GFP emulsified in Freund's adjuvant \\
\hline $\begin{array}{l}\text { Anti-rabbit } \\
\text { Alexa Fluor } 594\end{array}$ & Life Technologies & A21207 & 1256153 & Donkey & & \\
\hline $\begin{array}{l}\text { Anti-goat } \\
\text { Alexa Fluor } 594\end{array}$ & Life Technologies & A11058 & 1608643 & Donkey & & \\
\hline $\begin{array}{l}\text { Anti-chicken } \\
\text { Alexa Fluor } 488\end{array}$ & Life Technologies & A11039 & 1356650 & Goat & & \\
\hline
\end{tabular}

ripherin gene also showed a single band at approximately 58 kDa (Tseng et al., 2008; Xiao et al., 2008). Moreover, it was shown that the staining obtained with this antibody overlapped perfectly with that of eGFP-peripherin in PC12 cells (Tseng et al., 2008). As anticipated, this antibody produced filamentous staining of the neuronal perikarya in the nodose ganglion. Here, we used peripherin as a panneuronal marker for vagal afferents.

\section{Polyclonal goat antiserum against tyrosine hydroxylase (RRID:AB_10710873)}

The data from the manufacturer show that this antiserum detects a single 50-kDa band from rat, mouse, and human brain lysates. This antibody has been used to label the mouse striatum and the rat ventral tegmental area (García-Pérez et al., 2013; Biezonski et al., 2015). Omission of the antibody resulted in no staining. Here, we used the tyrosine hydroxylase (TH) antibody to label subsets of postsynaptic neurons in the dorsovagal complex. In our samples, this antiserum produced a staining pattern that was consistent with the distribution of TH-positive neurons in the mouse dorsovagal complex (Cork et al., 2015).

\section{Polyclonal goat anti-pro-MCH (RRID:AB_2237276)}

By Western blot, this antibody detects one band of 45-50 Kda, according to the manufacturer. Although the exact sequence of the immunogenic peptide is not available, Deurveilher et al. (2006) have discussed the observation that this antibody certainly detected $\mathrm{MCH}$ neurons in the lateral hypothalamus. For instance, they showed overlapping staining with another antibody and a lack of staining when the antibody was preadsorbed with the immunogen peptide (Deurveilher et al., 2006). Moreover, this antiserum did not label orexin-positive cells. In our laboratory, this antiserum exclusively labeled neurons in the lateral hypothalamus region, strongly suggesting specificity. The lateral hypothalamus was not stained when the primary antibody was omitted. Finally, another group showed that this antiserum did not immunolabel structures in mice lacking $\mathrm{MCH}$ neurons (Whiddon and Palmiter, 2013), further exhibiting its specificity.

\section{Polyclonal rabbit antiserum against $\mathrm{MCH}$ (RRID:}

\section{AB 10013632)}

According to Deurveilher et al. (2006), this antibody labels exactly the same cells as the pro-MCH antibody described above. The manufacturer also performed competitive radioimmunoassays to ascertain specificity. Incubation of the primary antibody with its immunogenic peptide prevented the labeling of the rat brain (Glavas et al., 2008). In this study, the distribution pattern of the $\mathrm{MCH}$-positive elements observed in the mouse brain was consistent with that described by other groups using other antibodies against $\mathrm{MCH}$ (Croizier et al., 2010).

\section{Double fluorescent immunohistochemistry}

The native fluorescence for ChR2-YFP was directly observed in the nodose ganglion and brainstem. In peripheral tissues, YFP was indirectly detected using an antiserum against GFP. After rinsing in phosphatebuffered saline (PBS), free-floating brain sections, whole mounts, or histological slides were incubated with primary antibodies [diluted in 3\% normal donkey serum (NDS; Jackson ImmunoResearch, West Grove, PA) and $0.3 \%$ Triton X-100 in PBS] at room temperature for 16-24 h. After several PBS washes, the tissues were then incubated with 1:500 to 1:1000 dilutions of the appropriate secondary antibodies for $1 \mathrm{~h}$. The tissue was then covered with Vectashield hard-set mounting medium with DAPI (H1500) and coverslipped. Table 1 summarizes the combinations of primary and secondary antibodies used in this study. Immunohistochemistry was performed at room temperature with gentle horizontal shaking. 
Table 2. List of reagents used for ISH (RNAscope probes from ACD)

\begin{tabular}{lllll}
\hline Gene & Accession no. & Target region & Catalog no., channel & Chromogenic label \\
CARTPT & NM_013732.7 & $11-860$ & $432001-c 1$ & DAB, brown \\
PMCH & NM_029971.2 & $4-652$ & $478721-c 1$ & DAB, brown
\end{tabular}

\section{In situ hybridization}

The tissue was processed for chromogenic ISH using the RNAscope 2.5 HD Assay (Brown) from Advanced Cell Diagnostic (Newark, CA). The hypothalami and left nodose ganglia from fed and fasted C57BI/6 mice were rapidly removed and directly frozen on a bed of dry ice. Fresh-frozen tissue was sectioned at $14 \mu \mathrm{m}$ using a cryostat and collected on SuperFrost slides. Following the manufacturer's protocol, the tissue was fixed in $10 \%$ formalin and pretreated with a protease-based solution (pretreatment 4) followed by hybridization at $40^{\circ} \mathrm{C}$ for $2 \mathrm{~h}$ in a humidity oven with the double- $Z$ oligo probes for prepro-CART and prepro-MCH listed in Table 2. Signal amplification was achieved using 3,3'-diaminobenzidine (DAB), and the tissue was counterstained with hematoxylin. Finally, hybridized slides were dehydrated in graded alcohols, immerged in xylene, and coverslipped with Permaslip mounting medium (Alban Scientific, St. Louis, MO).

\section{Confocal imaging and photomicrograph production}

Samples from $\mathrm{Na}_{v} 1.8-\mathrm{Cre}-\mathrm{ChR} 2-\mathrm{YFP}$ mice were scanned using a Leica SP5 confocal microscope. Oil
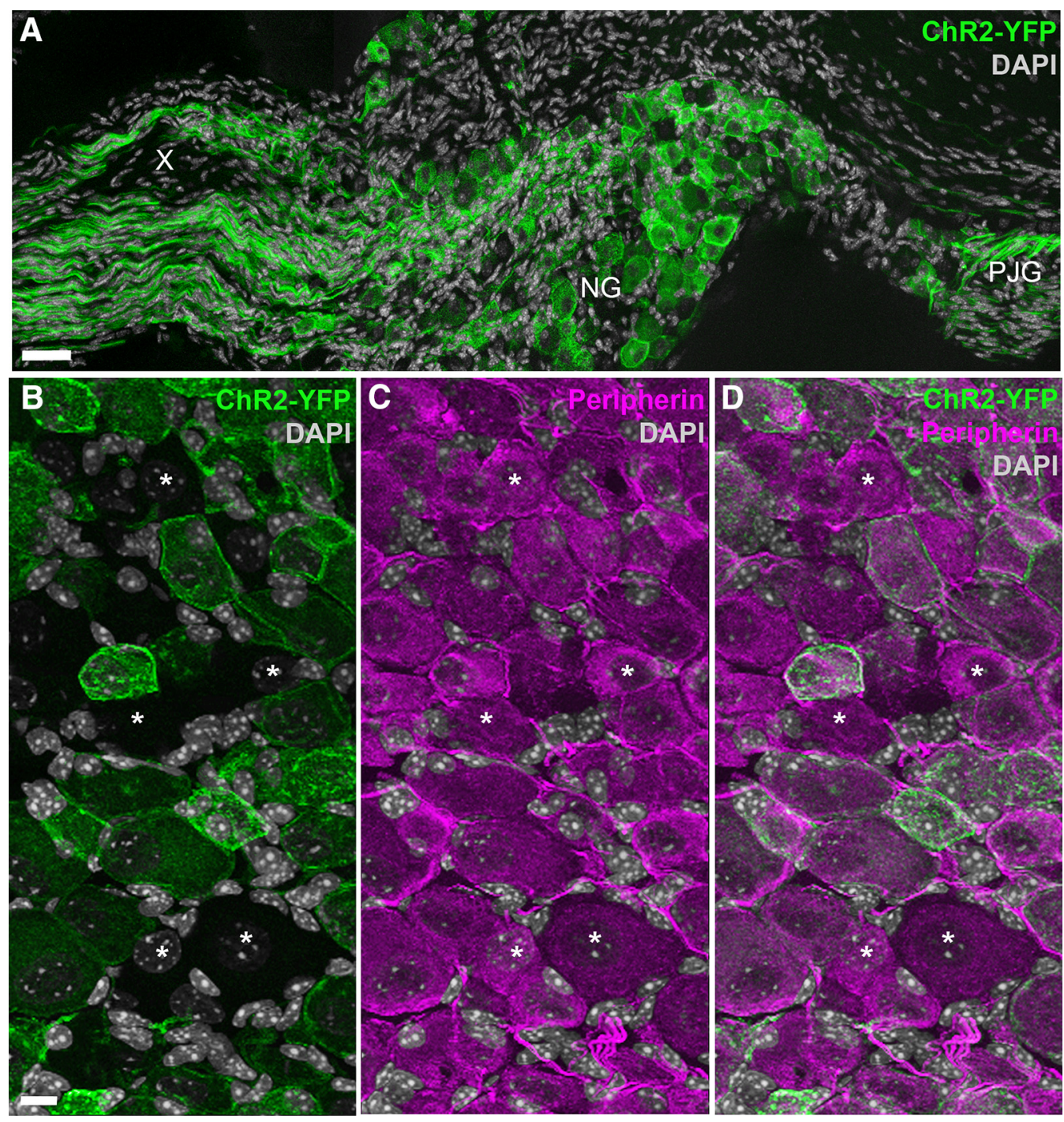

Figure 1. Distribution of ChR2-YFP fluorescence in the nodose ganglion of $\mathrm{Na}_{\mathrm{v}} 1.8-\mathrm{Cre}-\mathrm{ChR} 2-\mathrm{YFP}$ mice. $\boldsymbol{A}$, Many neuronal cell bodies and axons were brightly fluorescent in the nodose ganglion (NG) and petrosal-jugular ganglion (PJG) (three images were horizontally stitched together). $\boldsymbol{B}-\boldsymbol{D}$, Details of NG peripherin-labeled neurons (Alexa Fluor 594). ChR2-YFP is apparent in the membrane and cytoplasm of many NG neurons (but not all) $(\boldsymbol{B})$. Asterisks are positioned over representative peripherin-positive neurons that were not labeled with ChR2-YFP $(\boldsymbol{B}, \boldsymbol{C})$. X, cervical vagus nerve. Scale bars, $40 \mu \mathrm{m}$ in $\boldsymbol{A} ; 20 \mu \mathrm{m}$ in $\boldsymbol{B}$ (also applies to $\boldsymbol{C}, \boldsymbol{D}$ ). 

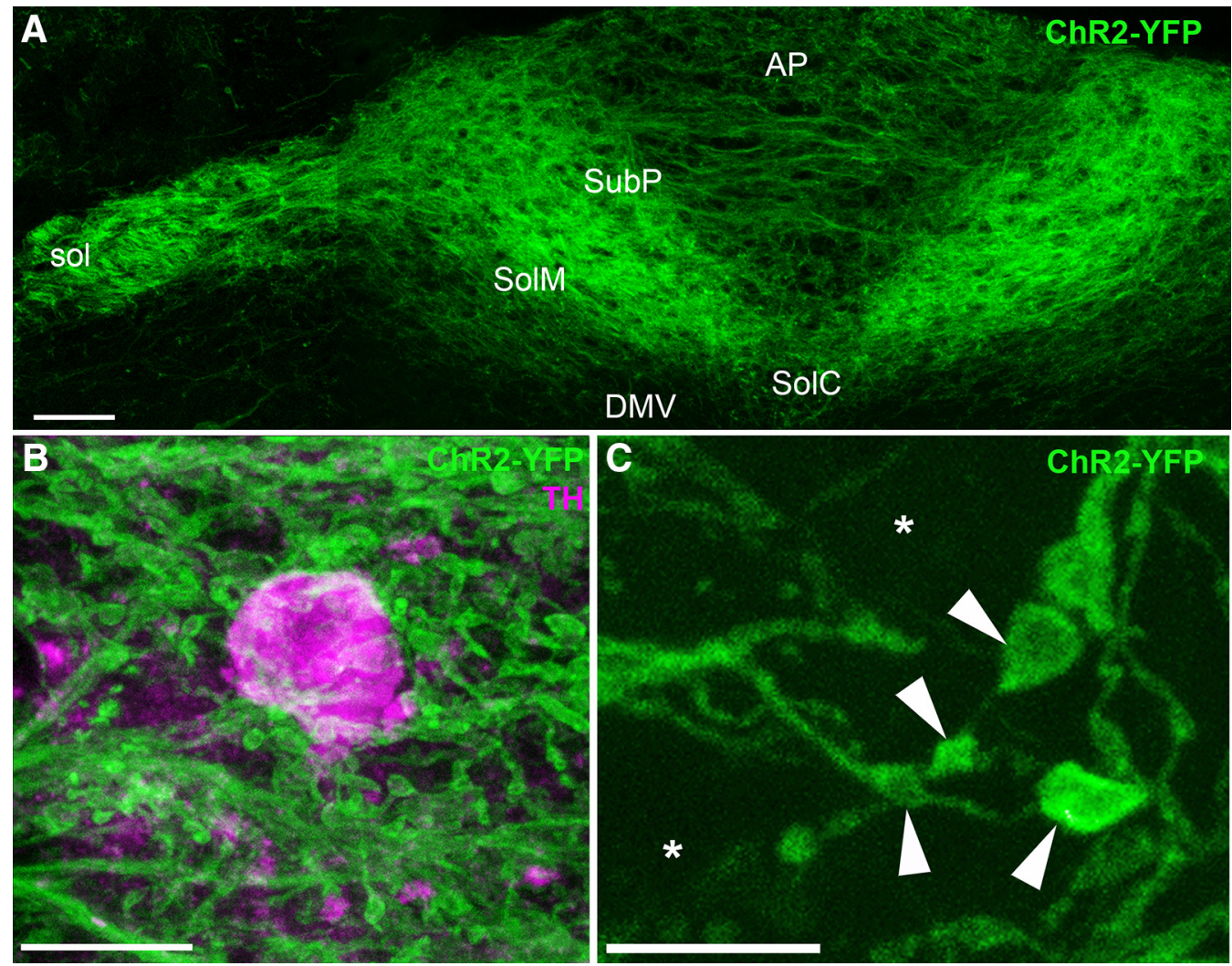

Figure 2. Distribution of ChR2-YFP fluorescence in the dorsovagal complex of $\mathrm{Na}_{\mathrm{v}} 1.8-\mathrm{Cre}-\mathrm{ChR} 2-\mathrm{YFP}$ mice. $\boldsymbol{A}$, Vagal afferents terminating in the AP and NTS were labeled with ChR2-YFP (three horizontally stitched images). $\boldsymbol{B}$, Highly varicose ChR2-YFP-labeled axons circling the cell body of one TH-positive neuron (Alexa Fluor 594) located in the NTS. $\boldsymbol{C}$, Single optical section of ChR2-YFP-labeled axons in the AP revealing thin varicose axons of varying sizes. Asterisks are positioned over the presumptive locations of the postsynaptic cell bodies, whereas arrowheads indicate representative vagal varicosities. DMV, dorsal nucleus of the solitary tract; sol, solitary tract; commissural part of the nucleus of the solitary tract; SolDM, dorsomedial part of the nucleus of the solitary tract; SolM, intermediate part of the nucleus of the solitary tract; SubP, subpostrema area. Scale bars, $60 \mu \mathrm{m}$ in $\boldsymbol{A} ; 5 \mu \mathrm{m}$ in $\boldsymbol{B}$ and $\boldsymbol{C}$.

immersion $40 \times$ and $63 \times$ objectives were used. The gain and laser intensity were slightly adjusted for each tissue; however, the same scanning parameters were applied when comparing the same tissues from different feeding groups. The line average was 8 or 16 . The step increase in the $z$-axis was usually $0.35 \mu \mathrm{m}$, and the total number of optical sections in each stack was 10-20. Most of the images in the study were merged into one color and projected onto a single plane, unless mentioned otherwise in the legend. Single optical sections were used for the estimates and colocalization studies. ImageJ (http:// rsb.info.nih.gov/ij/) was used to convert all our confocalacquired images (lif format) into TIFF images (RGB, 300 dpi) and generate scale bars. CART-positive cells were subjectively evaluated by scaling cell profiles clearly containing immunoreactivity within the outline of the YFPlabeled structures that conformed well to the shapes of these structures.

Adobe Photoshop CS5.1 (Adobe Systems, San Jose, $\mathrm{CA}$ ) was used to combine the digital images into annotated plates. In some instances, several images were stitched together, as indicated in the legend. The contrast and brightness were uniformly adjusted by adding one adjustment layer. Finally, DAPI-labeled structures were converted to grayscale for better contrast, and red-green fluorescence images were converted to magenta-green for colorblind readers.

\section{Estimates of double-labeled cells and axons}

We estimated the percentage of ChR2-YFP-labeled vagal afferents by counting the cell profiles that were double labeled for peripherin and ChR2-YFP. Likewise, we counted the neurons that were double labeled for CART and ChR2-YFP in the nodose ganglion. A neuron was considered double labeled when the shape of the YFP-positive profile corresponded to that of the CART or peripherin-stained profiles. The neurons were counted in digital images obtained with a Zeiss microscope (Imager $\mathrm{ZI}, 20 \times$ objective) equipped with a scanning stage and attached to the ApoTome system and a digital camera (Axiocam MRm). A desktop computer running Axiovision 4.7 was used to produce the digital images. The neurons in a 1:5 series of sections across the nodose ganglion were counted by a blinded observer. To evaluate the relative intensity of fluorescence in CART-labeled cells, we used a method described in the literature (Fang et al., 2002) with slight modifications. Using ImageJ, the mean absorbance of outlined CART-positive profiles was mea- 

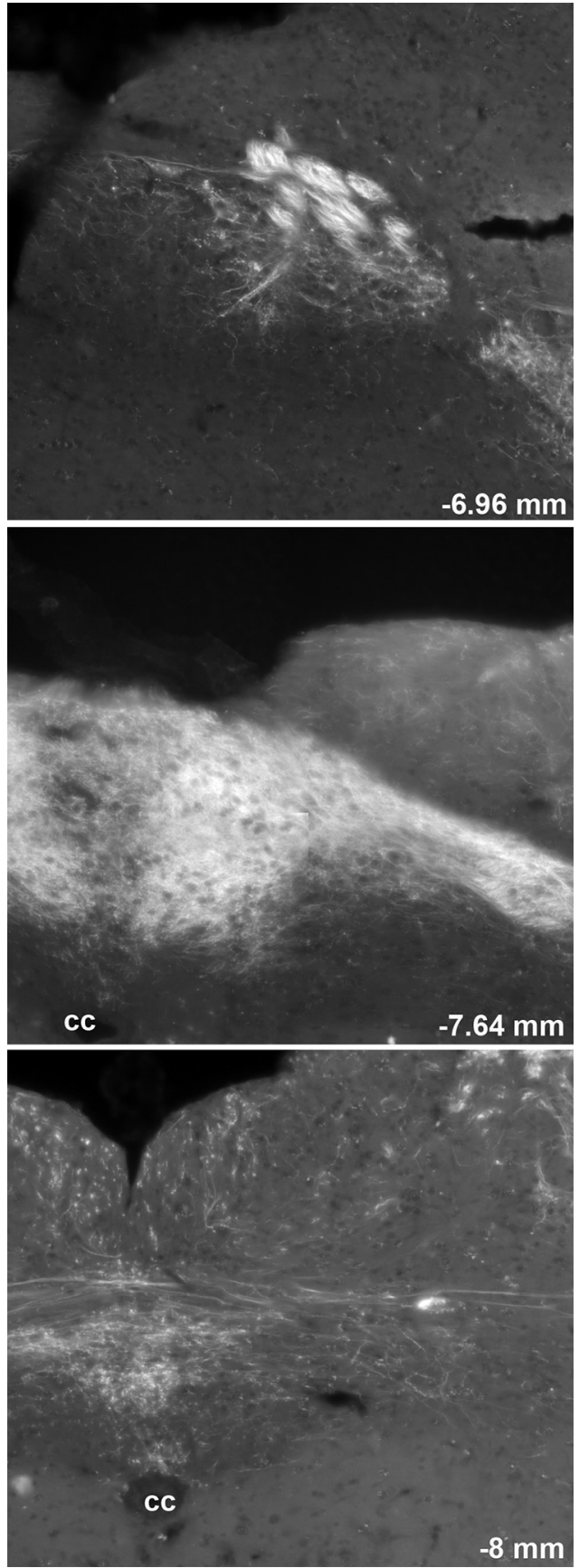

Figure 3. Distribution of ChR2-YFP fluorescence throughout the rostrocaudal extension of the dorsovagal complex of one representative $\mathrm{Na}_{v} 1.8-\mathrm{ChR} 2-$ YFP mouse. Several digital images were stitched together (epifluorescence with Apotome filter). The number in the bottom right corner indicates the approximate distance from Bregma according to the Franklin and Paxinos Mouse Brain Atlas (Third Edition). 4v, fourth ventricle; cc, central canal.

sured using measurement tools. The average of the mean absorbance of one negative profile in each tissue section of chow-fed mice was used as our $0 \%$ intensity (a). The average of the mean absorbance of one most intensely stained profile in each tissue section of chow-fed mice was used as $100 \%$ intensity (b). The intensity of the

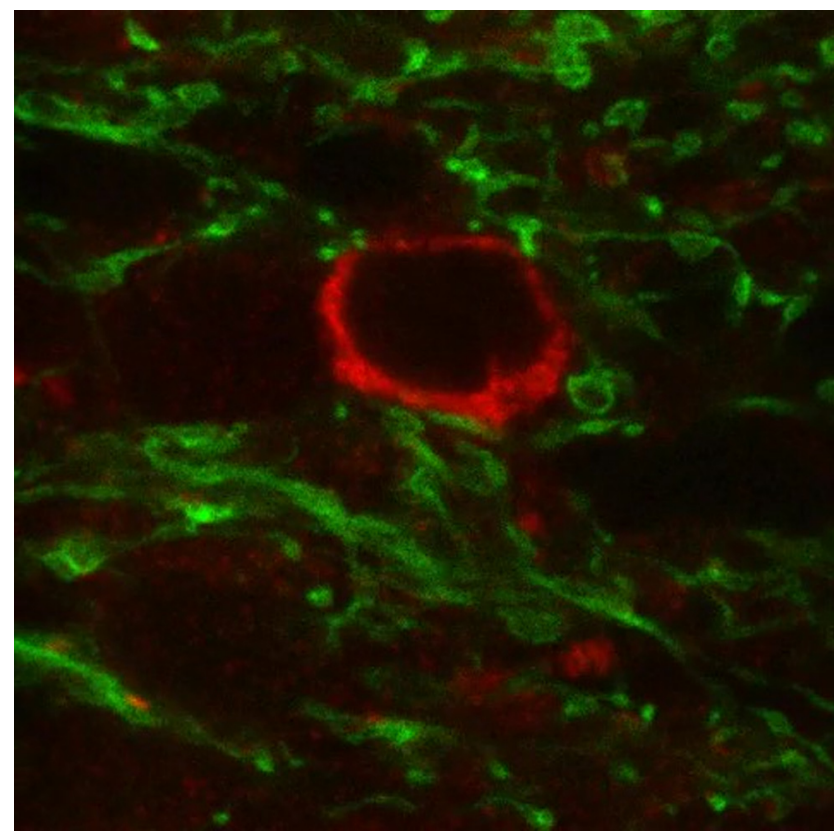

Movie 1. File compilation of a $z$-stack of ChR2YFP-labeled axons (green) around one THpositive neuron (Alexa Fluor 594) in the AP of the $\mathrm{Na}_{v} 1.8-\mathrm{Cre}-\mathrm{ChR} 2-\mathrm{YFP}$ mouse. Note the varicosities in close apposition to the outline of the $\mathrm{TH}$-positive neuron.

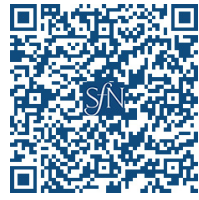

measured profiles was scaled between the minimal and maximal values as follows:

\section{Relative intensity of CART-labeled profile $=$ (measured mean $-a) /(b-a) \times 100$.}

The measurements were repeated in a large number of individual cell profiles as indicated in our graph. Data were expressed as the relative intensity (\%) of individual CART cells compared to the darkest-stained cells. This method allowed us to easily visualize the full range of immunoreactivity of CART cells across the different feeding groups. Cell profiles were categorized according to their relative immunoreactivity as containing low $(0$ to $<25 \%)$, medium ( 25 to $<75 \%$ ), or high (75 to $>100 \%$ ) immunoreactivity. Finally, we calculated the frequency of neurons falling into each category across feeding groups. None of the estimates described above were meant to provide absolute counts, but rather relative estimates across different feeding conditions. Thus, we did not correct our data for double counting and did not use the stereological technique. The graphs were constructed using GraphPad Prism 7.01.

The estimates described below were performed in a 1:5 series of sections using digital images of single optical sections acquired with a confocal microscope $(63 \times$, zoom 6). Counting was performed by a blinded experimenter. The percentage of CART-positive varicosities in the area postrema (AP) was evaluated. Double-labeled varicosities were considered when CART staining was clearly contained within the boundaries of each ChR2YFP-labeled varicosity. Second, the diameters of the 

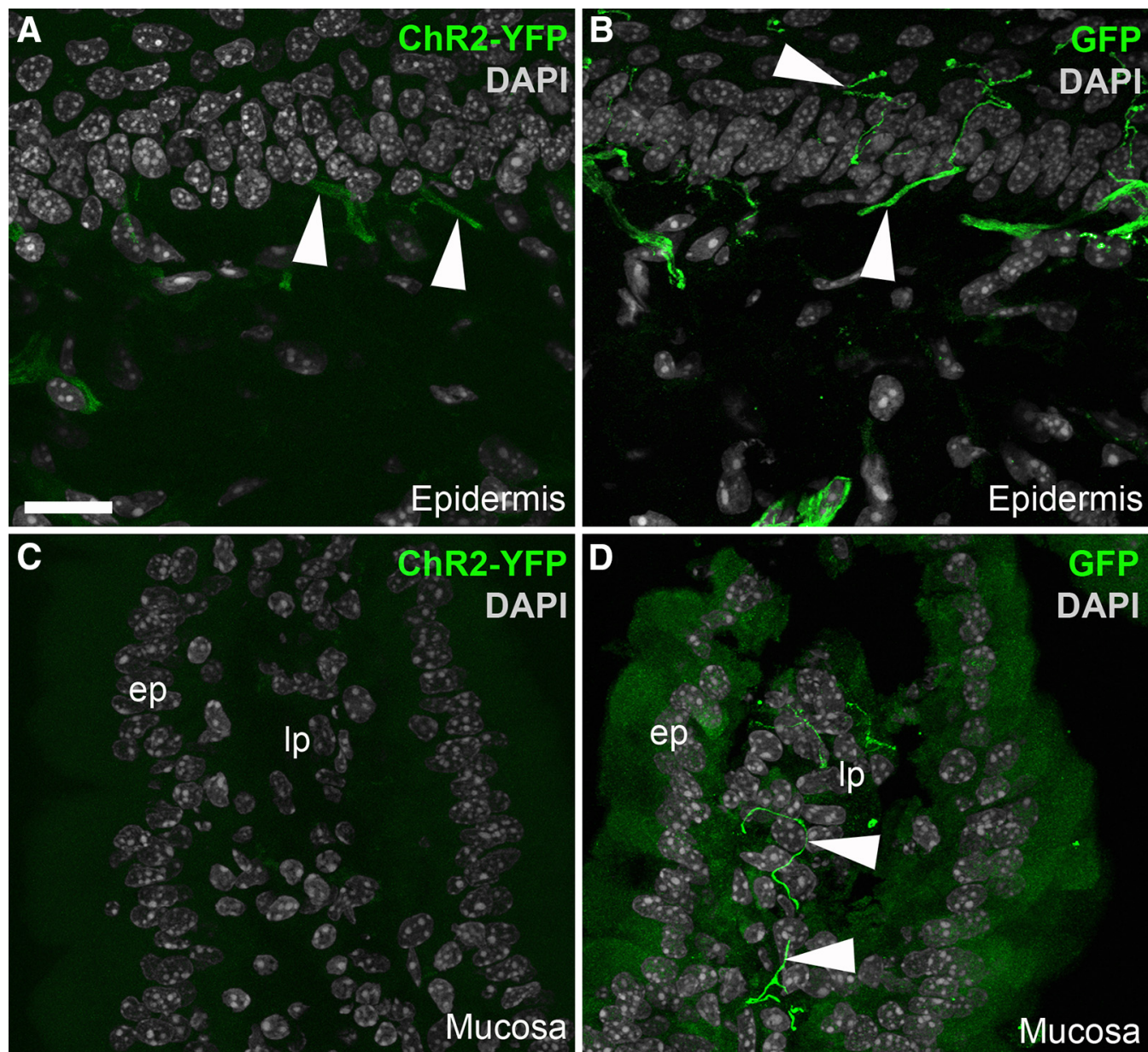

Figure 4. Identification of ChR2-YFP-positive fibers in peripheral tissues from $\mathrm{Na}_{\mathrm{v}} 1.8-\mathrm{Cre}-\mathrm{ChR} 2-\mathrm{YFP}$ mice. $\boldsymbol{A}$, Weakly fluorescent structures resembling nerve endings (arrowheads) were observed in the epidermis of the forepaw. $\boldsymbol{B}$, GFP immunolabeling greatly enhanced the labeling of individual axons ramifying into the epidermis. $\boldsymbol{C}$, We could not detect endogenous YFP fluorescence in the duodenal mucosa before immunolabeling. $\boldsymbol{D}$, YFP-labeled axons were evident in the lamina propria (Ip) when the tissue was stained for GFP. The antibody produced a small amount of nonspecific background staining in the epithelium (ep). Arrowheads indicate representative YFP-positive fibers. Scale bars, $20 \mu \mathrm{m}$ in $\boldsymbol{A}$ (also applies to $\boldsymbol{B}-\boldsymbol{D}$ ).

ChR2-YFP-labeled axons and varicosities in the AP were evaluated. The counts and measurements were collected using ImageJ measuring tools.

Immunofluorescence in the rat was captured using a digital camera (Axiocam) attached to a Zeiss microscope Imager ZI equipped with the Apotome system. Several images of the rat nodose ganglion taken at $40 \times$ were stitched together using Axiovision 4.7 software. The density of CART-positive cells in the rat nodose ganglion was evaluated using Axiovision 4.7. A blinded observer manually counted the number of cell profiles that were immunoreactive for CART. The number of profiles was divided by the surface of tissue occupied by the nodose ganglion.

ISH signals for prepro-CART mRNA were analyzed on DAB-labeled ganglia counterstained with hematoxylin. Images were taken using the bright-field optics of the Zeiss Axioskop 2 microscope and Axiovision 4.8 software. The percentage of prepro-CART-expressing profiles was estimated by manually counting clearly identifiable neuronal profiles with or without DAB. The inten- sity of the hybridization signals was further evaluated by subjectively scaling neuronal profiles with low $(<20$ DABpositive dots per profile), medium (dense accumulation of DAB with large areas of the cytoplasm still visible), or high (dense accumulation of DAB covering almost entirely the cell profile) signals. We then calculated the frequency of profiles falling into each category across feeding groups.

\section{Results}

\section{Tracing the vagal afferents using $\mathrm{Na}_{\mathrm{v}} 1.8-\mathrm{Cre}-\mathrm{ChR2}$} YFP mice

We first tried to establish the usefulness of $\mathrm{Na}_{\mathrm{v}} 1.8-\mathrm{Cre}-$ ChR2-YFP mice in labeling vagal $\mathrm{C}$-fibers. In the nodose ganglion, the soma of the vagal afferents and their proximal axons showed robust endogenous green fluorescence (Fig. 1A). ChR2-YFP was clearly visible, without the need for immunostaining, in the membrane and cytoplasm of many vagal afferents (Fig. $1 A, B$ ). We estimated that $82 \pm 2 \%(n=4)$ of the vagal afferents that stained for peripherin, a panneuronal marker in the peripheral ner- 

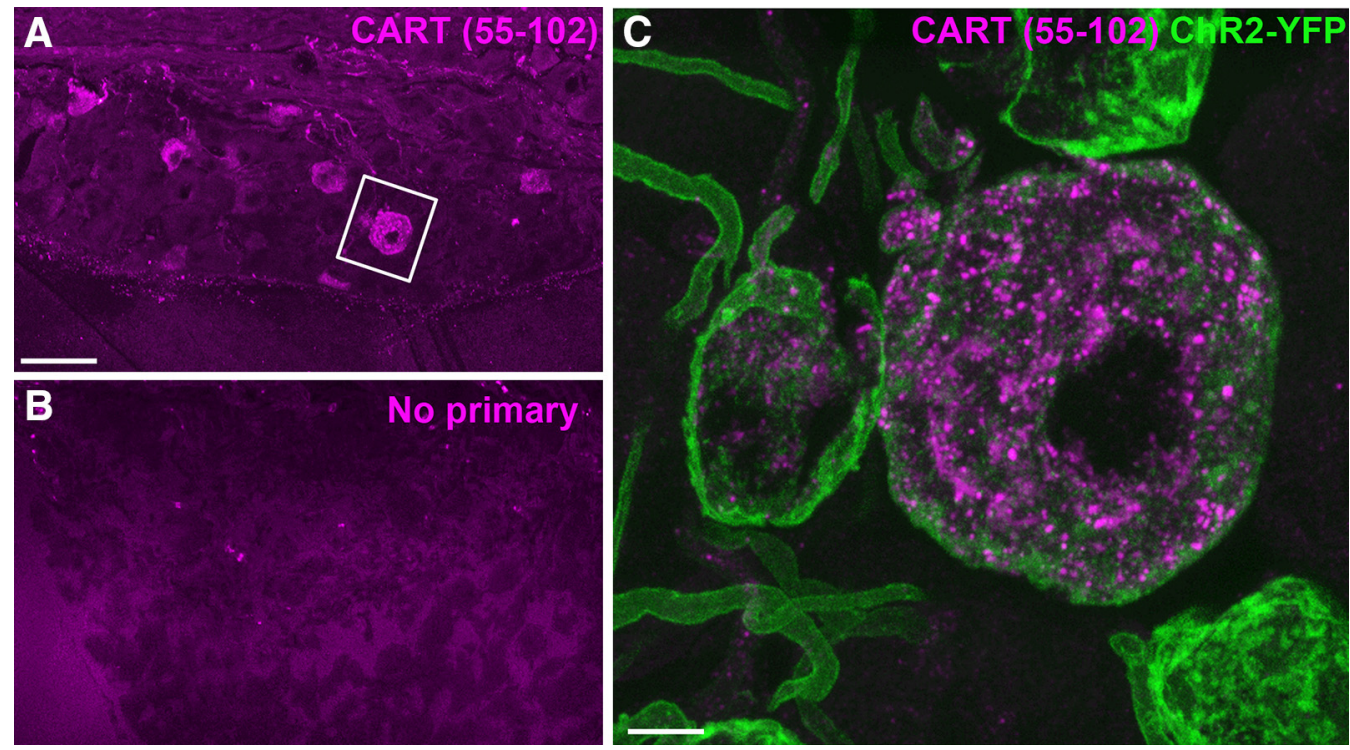

Figure 5. CART(55-102) detection in the nodose ganglion (NG) of $\mathrm{Na}_{\mathrm{v}} 1.8-\mathrm{Cre}-\mathrm{ChR} 2-\mathrm{YFP}$ mice. $\boldsymbol{A}$, CART-positive cells (Alexa Fluor 594) resembling neurons were observed throughout the NG. The two cells located in the inset are represented at high magnification in $\boldsymbol{C}$. B, Omission of the primary antibody eliminated CART immunoreactivity. Only a few debris and background could be observed in the NG. C, Two adjacent ChR2-YFP-, CART-positive neurons are shown. CART is detected in vesicle-like structures in the cytoplasm and proximal axon. The larger neuron contained more immunoreactivity than the smaller neuron. Two other YFP-labeled neurons did not contain CART. Scale bars, $50 \mu \mathrm{m}$ in $\boldsymbol{A}$ and $\boldsymbol{B} ; 5 \mu \mathrm{m}$ in $\boldsymbol{C}$.

vous system (Gorham et al., 1990), were also positive for ChR2-YFP (Fig. 1B-D).

In addition, ChR2-YFP labeled the membranes of the vagal terminals within the dorsovagal complex (Figs. 2A, 3 ). Although we observed a few isolated ChR2-YFPlabeled neurons in the forebrain (mainly in the cortex and striatum), no neurons were detected in the hypothalamus or brainstem (not shown). Thus, the ChR2-YFP-labeled fibers observed in the dorsovagal complex were essentially derived from the nodose ganglion. The densest innervation was observed in the dorsal and medial parts of the nucleus of the solitary tract (NTS), as well as the solitary tract itself (Fig. 2A). Innervation was less dense in the AP and other parts of the NTS (Fig. 2A). The innervation of the dorsovagal complex was very dense, forming bundles of intermingled axons circling the putative location of the postsynaptic neurons. For example, ChR2-YFP varicosities accumulated in the vicinity of $\mathrm{TH}$-positive neurons in the AP and NTS (Fig. 2B). Although it was difficult to distinguish individual axons and varicosities at low magnification, optical sectioning at higher magnification $(63 \times)$ revealed individual thin axons (average diameter $0.3 \pm 0.0 \mu \mathrm{m} ; n=3$ ) decorated with boutons and varicosities resembling presynaptic terminals (average diameter $0.9 \pm 0.0 \mu \mathrm{m} ; n=3$ ) (Fig. 2C). Movie 1 is a file compilation of a z-stack of ChR2-YFP-labeled axons (green) around one TH-positive neuron (red).

ChR2-YFP was also transported toward peripheral tissues that were innervated by C-fibers (Fig. 4). However, the native fluorescence for ChR2-YFP was much weaker in the periphery than in the ganglia or brain. For instance, low to nearly undetectable levels of endogenous YFP fluorescence were seen in the epidermis (Fig. 4A) and intestinal mucosa (Fig. 4C). Immunostaining with an anti-
GFP antiserum successfully marked axons and specialized sensory endings in those tissues (Fig. $4 B, D$ ). Thus, the subsequent experiments depicting ChR2-YFP in the peripheral tissues were performed using GFP immunofluorescence. Overall, $\mathrm{Na}_{v} 1$.8-Cre-ChR2-YFP mice allowed assessment of the detailed morphology of C-fibers in many visceral tissues (not shown). Importantly, no cell bodies were ever labeled in peripheral organs.

\section{Distribution and regulation of in vagal afferents of metabolically challenged mice}

In the nodose ganglion of $\mathrm{Na}_{\mathrm{v}} 1.8-\mathrm{Cre}-\mathrm{ChR} 2-\mathrm{YFP}$ mice, immunoreactivity for CART(55-102) was detected in the soma and proximal axons of many neurons (Figs. $5 A, C$, 6). The nodose ganglion neurons were not stained when the CART primary antibody was omitted (Fig. 5B). In agreement with previous works (Broberger et al., 1999; Zheng et al., 2002; Scruggs et al., 2003), immunoreactivity for CART was evident in large puncta around the cell nucleus and within the proximal axon (Fig. 5B). Approximately $55 \%$ of ChR2-YFP-labeled neurons were CARTpositive (Figs. 6, 7A), and $>99 \%$ of CART-positive cells were labeled with ChR2-YFP. CART staining in the nodose ganglion looked identical in fed, fasted, and obese animals when observed under blinded conditions (Fig. $6 A-F$ ). According to our estimates, the percentage of ChR2-YFP-labeled neurons containing CART was identical across the feeding groups (Fig. 7A). Because CART immunoreactivity varied in intensity between neurons, we also examined the relative intensity of CART(55102) immunoreactivity in a large number of cell profiles (Fig. 7C). The percentages of cells with low, medium, and high immunoreactivity were identical across the feeding groups (Fig. 7C). 

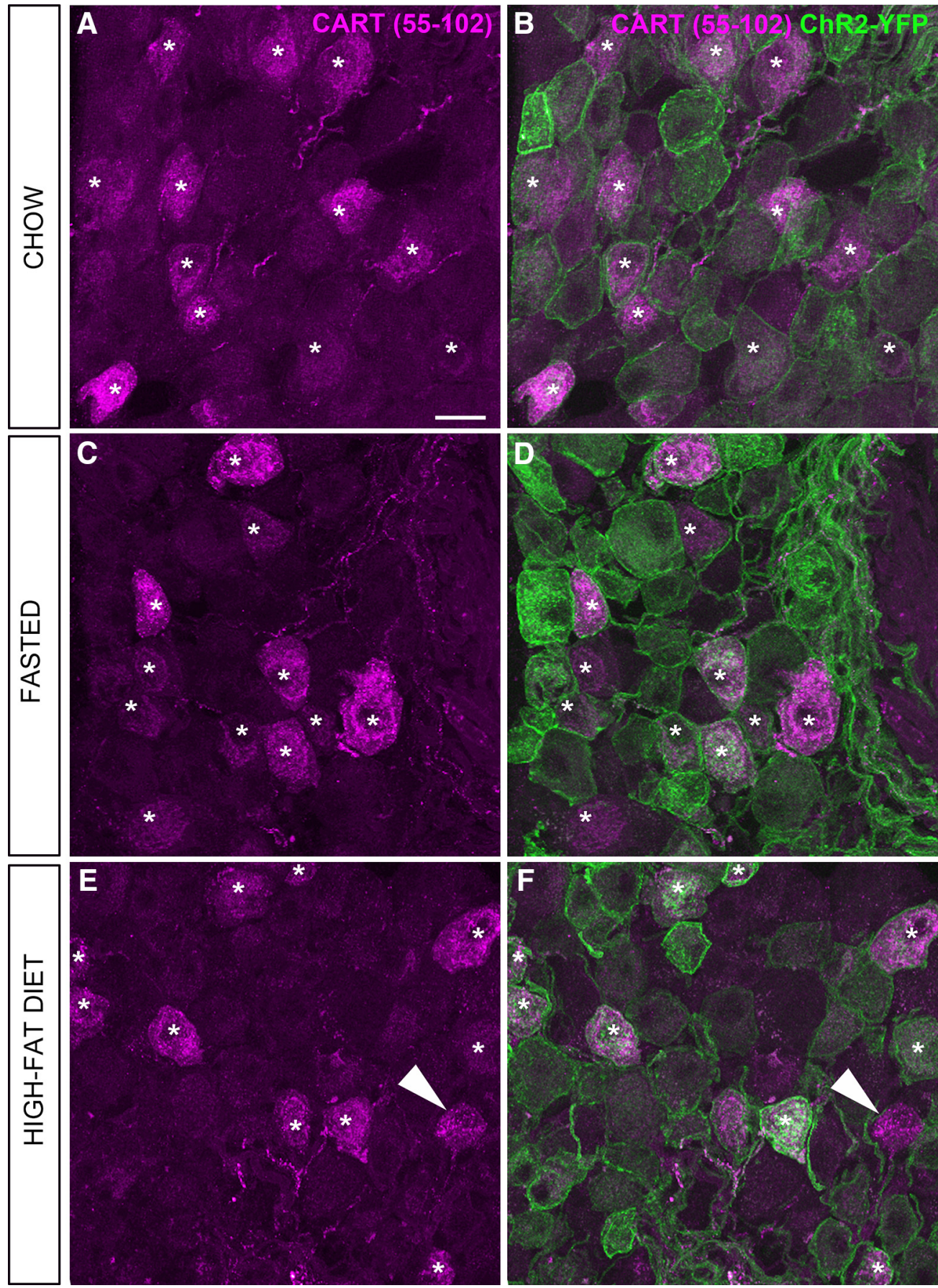

Figure 6. CART(55-102) immunolabeling of the nodose ganglion (NG) of metabolically challenged $\mathrm{Na}_{\mathrm{v}} 1.8-\mathrm{Cre}-\mathrm{ChR} 2-\mathrm{YFP}$ mice. $\boldsymbol{A}$, C, $\boldsymbol{E}$, CART-positive perikarya (Alexa Fluor 594) across the feeding groups. $\boldsymbol{B}, \boldsymbol{D}, \boldsymbol{F}, \mathrm{CART}$ staining and endogenous ChR2-YFP fluorescence delineate the outline of the vagal afferents. Asterisks are positioned over representative CART-positive cells. Note that CART immunoreactivity is almost always contained within the cell membrane of the YFP-labeled cells, with a few rare exceptions (arrowhead). By visual inspection, the CART distribution pattern and intensity appeared comparable across the feeding groups. Scale bars, $20 \mu \mathrm{m}$ in $\boldsymbol{A}$; applies to all images.

Most of the studies on the impact of fasting on vagal CART have been performed in rats. To rule out the possibility of species differences, we examined CART in fed and fasted rats (Fig. 8). The distribution and intensity of CART staining in the nodose ganglion looked identical in fed and fasted rats when observed under blinded conditions (Fig. 8). Moreover, the density of CART-positive profiles across the ganglion was not significantly different in fed $\left(125 \pm 18 \mathrm{cells} / \mathrm{mm}^{2}, n=3\right)$ and fasted (160 \pm 27 cells $\left./ \mathrm{mm}^{2}, n=3\right)$ rats.

We also assessed CART immunoreactivity in the vagal terminals in the dorsovagal complex. CART(55-102) immunoreactivity was observed throughout the entire dorsovagal complex and included both neuronal soma and 
A

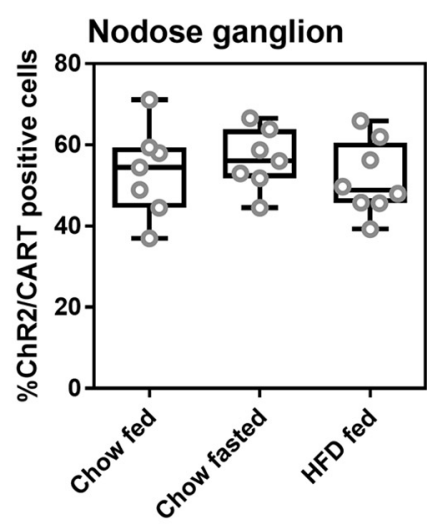

C

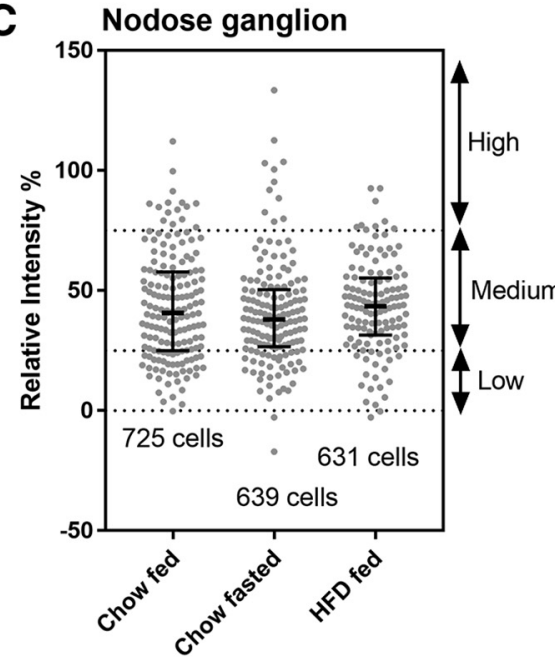

B

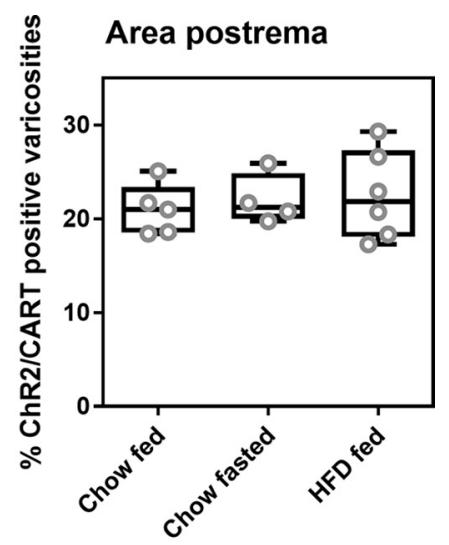

D

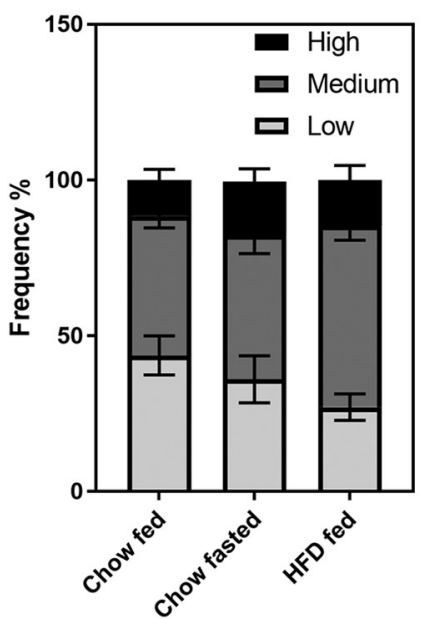

Nodose ganglion pCARTmRNA

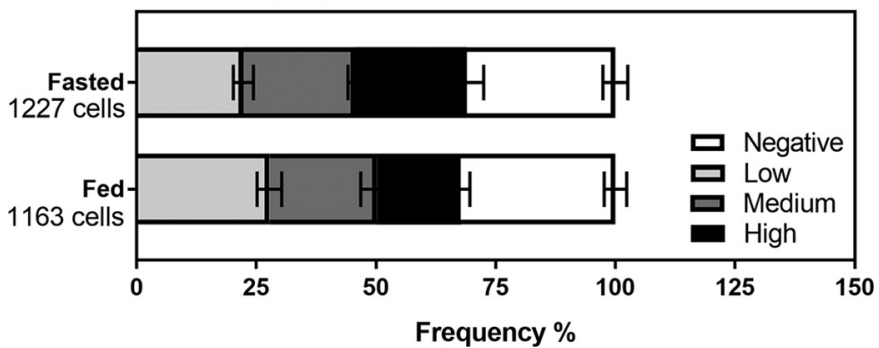

Figure 7. Estimates of CART-positive neurons and afferents across the feeding groups. $\boldsymbol{A}$, The percentage of YFP- and CART-positive neurons in the nodose ganglion (NG) of $\mathrm{Na}_{\mathrm{v}} 1.8$-Cre-ChR2-YFP mice was not influenced by feeding status $(n=7-8$ per group). $\boldsymbol{B}$, The percentage of CART-positive varicosities in the AP was identical in $\mathrm{Na}_{v} 1$.8-Cre-ChR2-YFP mice under different feeding conditions. Data are expressed as the average of the mean percentage \pm maximum values ( $n=7-8$ per group). Each circle represents one value from one mouse. $\boldsymbol{C}$, Frequency of CART immunoreactivity profiles with varying intensity across feeding groups ( $n=7$ per group). On the left, frequency scattergraph of distributions of individual CART-positive cell profiles with median and interquartile range. Each gray dot is one cell profile. The total number of profiles examined in each group is annotated. On the right, the same data were represented as stacked bars after categorizations of immunoreactivity level. Data are provided as mean percentage \pm SEM. $\boldsymbol{D}$, Frequency of cells expressing pCART mRNA in the nodose ganglia of fed $(n=4)$ and fasted $(n=3)$ wild-type mice. Cells were scaled based on the intensity of hybridization signals. The total number of profiles examined in each group is annotated. Stacked bars provide mean percentage \pm SEM.

fibers (Fig. 9A). Across the feeding groups, the distribution and intensity of CART immunoreactivity was directly comparable (Fig. 9A-C). CART immunoreactivity was observed in ChR2-YFP axons and varicosities in the AP and commissural part of the nucleus of the solitary tract (SolC), in agreement with the results of Zheng et al. (2002). In these regions, CART immunoreactivity corresponded well to the shape of the YFP-labeled varicosities (Fig. 9G,H). However, not all CART-positive elements corresponded to YFP-labeled structures, and in other parts of the dorsovagal complex, double-labeled axons were rarely observed (not shown). In the AP, CART(55-102) was present in approximately $22 \%$ of the ChR2-YFPlabeled varicosities (Fig. 7B). In agreement with our re- 

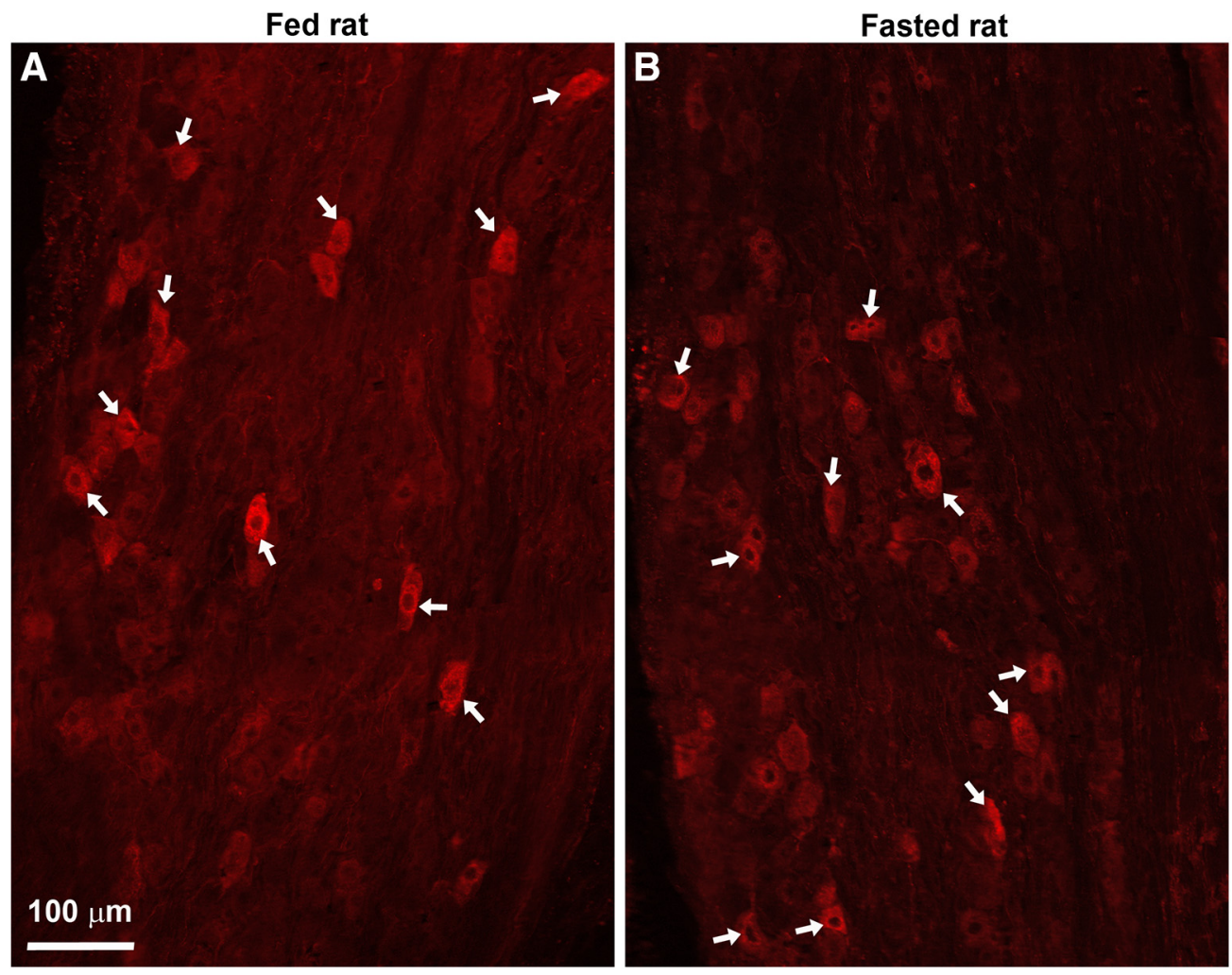

Figure 8. $\boldsymbol{A}, \boldsymbol{B}, \mathrm{CART}(55-102)$-positive neurons in the nodose ganglia of lean Zucker rats. Several digital images were stitched together (epifluorescence with Apotome filter). Many CART-positive neurons (Alexa Fluor 594) were observed in the nodose ganglion of fed and fasted rats. White arrows indicate examples of CART neurons. Scale bar, $100 \mu \mathrm{m}$ in $\boldsymbol{A}$; applies to $\boldsymbol{B}$.

sults in the nodose ganglion, our estimates showed identical percentages of varicosities that were colabeled for CART and ChR2-YFP in the AP of the fed, fasted, and high-fat-diet-fed animals (Fig. 7B). We did not notice obvious differences in the shape, amount, and distribution of ChR2-YFP-labeled fibers across the feeding groups (Fig. 9D-F).

Finally, we assessed the expression of prepro-CART mRNA in the nodose ganglia of fed and fasted wild-type mice. Using chromogenic ISH, prepro-CART mRNA was detected at high levels in select hypothalamic nuclei known to express CART (Fig. 10A). Robust signals for prepro-CART mRNA were also present in nodose ganglia of fed and fasted mice (Fig. 10B,C). Variable amounts of $D A B$ accumulated in the soma of many vagal sensory neurons, including in the fasted condition (Fig. 10D). The percentage of prepro-CART-expressing cells and the relative intensity of hybridization signal per cell did not significantly change after fasting (Fig. 7D).

\section{Absence of $\mathrm{MCH}$ in vagal afferents of metabolically challenged mice}

Because $\mathrm{MCH}$ has been reported to be produced in CART afferents in response to fasting, we sought to evaluate the presence of both pro-MCH and $\mathrm{MCH}$ in our mice. First, we used an antiserum against pro- $\mathrm{MCH}$ that preferentially stained the perikarya. We successfully detected immunoreactivity for prepro- $\mathrm{MCH}$ in the perikarya of neurons in the lateral hypothalamus (Fig. 11A). The lateral hypothalamus neurons were not stained when the pro$\mathrm{MCH}$ antibody was omitted (not shown). We were unable to see any immunoreactivity for pro- $\mathrm{MCH}$ in the nodose ganglion of $\mathrm{Na}_{v} 1.8-\mathrm{Cre}-\mathrm{ChR} 2-\mathrm{YFP}$ mice, even in the fasted mice (Fig. 11B). Identical results were obtained in samples incubated with higher concentrations of antibody (up to 1:100; data not shown). Second, we used an antiserum against $\mathrm{MCH}$ itself. $\mathrm{MCH}$ immunoreactivity was observed in axons across the forebrain; however, the dorsovagal complex of the fed, fasted, and obese animals contained very little MCH (Fig. 11C,D). Typically, isolated $\mathrm{MCH}$-positive varicose axons were observed in the ventral region of the medial part of the nucleus of the solitary tract (SolM), where the YFP-labeled fibers were relatively sparse (Fig. 11C,D). These $\mathrm{MCH}$-positive axons never colocalized with YFP-labeled axons, further confirming that vagal afferents do not produce $\mathrm{MCH}$. To rule out the possibility of species differences, we also examined pro$\mathrm{MCH}$ in the nodose ganglion of fed and fasted rats. Consistent with our mouse data, we were not able to detect immunoreactivity (data not shown).

To rule out the possibility of a false-negative result, we also assessed the expression of prepro-MCH mRNA in the nodose ganglia of fed and fasted wild-type mice. As expected, chromogenic ISH revealed very intense signals in the lateral hypothalamus (Fig. 10E). In contrast, the rest of the brain and the nodose ganglion were completely devoid of signal, regardless of the nutritional status of the mice (Fig. 10F-H). 

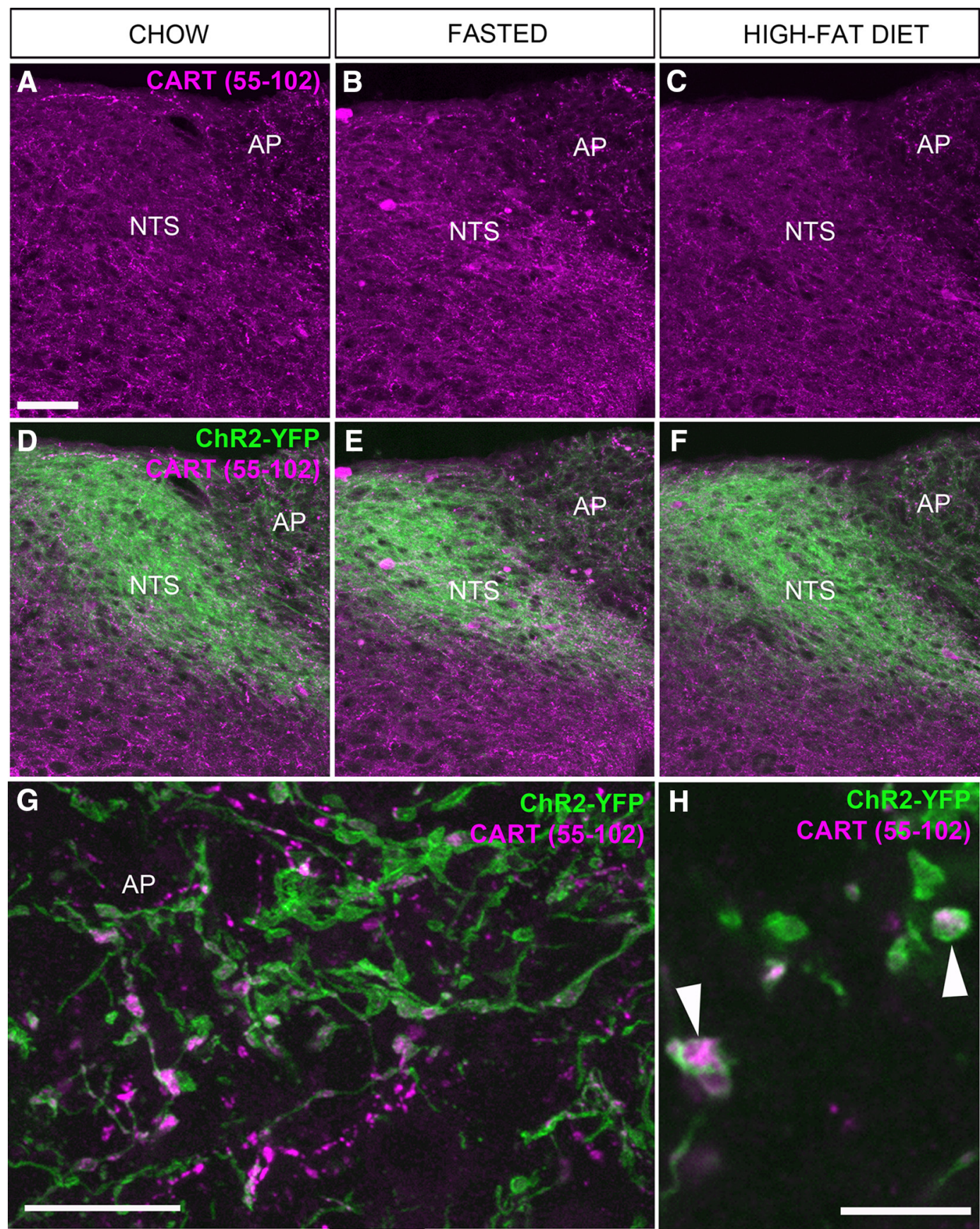

Figure 9. CART(55-102) immunolabeling of the dorsovagal complex of metabolically challenged $\mathrm{Na}_{\mathrm{v}} 1.8-\mathrm{Cre}-\mathrm{ChR2}-\mathrm{YFP}$ mice. $\boldsymbol{A}$, $\boldsymbol{B}$, $\boldsymbol{C}$, CART-positive (Alexa Fluor 594) perikarya and fibers of various origins were observed throughout the NTS and AP. We noticed a trend toward increased immunoreactivity in the fasted groups. However, our estimates (see Fig. 6) indicate that the levels of CART in vagal afferents remained unchanged across feeding conditions. $\boldsymbol{D}, \boldsymbol{E}, \boldsymbol{F}, \mathrm{CART}$ immunoreactivity combined with endogenous ChR2-YFP fluorescence. G, CART was very abundant in the AP. In particular, many YFP-labeled varicosities of vagal origin were enriched for CART. However, we also observed CART immunoreactivity that was not contained in ChR2-YFP-labeled fibers. $\boldsymbol{H}$, High magnification of the distribution of CART immunoreactivity in the vagal fibers of the AP in a single optical plan. Of note, CART frequently labeled the cytoplasm contained within the YFP-labeled varicosities, which are indicated by arrowheads. Scale bars, $60 \mu \mathrm{m}$ in $\boldsymbol{A}$, applies to $\boldsymbol{B}-\boldsymbol{F} ; 15 \mu \mathrm{m}$ in $\mathbf{G} ; 5 \mu \mathrm{m}$ in $\boldsymbol{H}$.

\section{Absence of CART immunoreactivity in gastrointestinal endings}

In the vagus nerve itself, we did not observe CART immunoreactivity in any YFP-labeled axons (Fig. 12A). In the gastrointestinal tract, abundant CART immunoreactiv- ity was observed, likely originating from postganglionic neurons (Calupca et al., 2001; Ekblad et al., 2003; Gonsalvez et al., 2010) and vagal efferents (Zheng et al., 2002). In those tissues, CART staining was observed in enteric neurons and fibers running closely to ChR2-YFP 

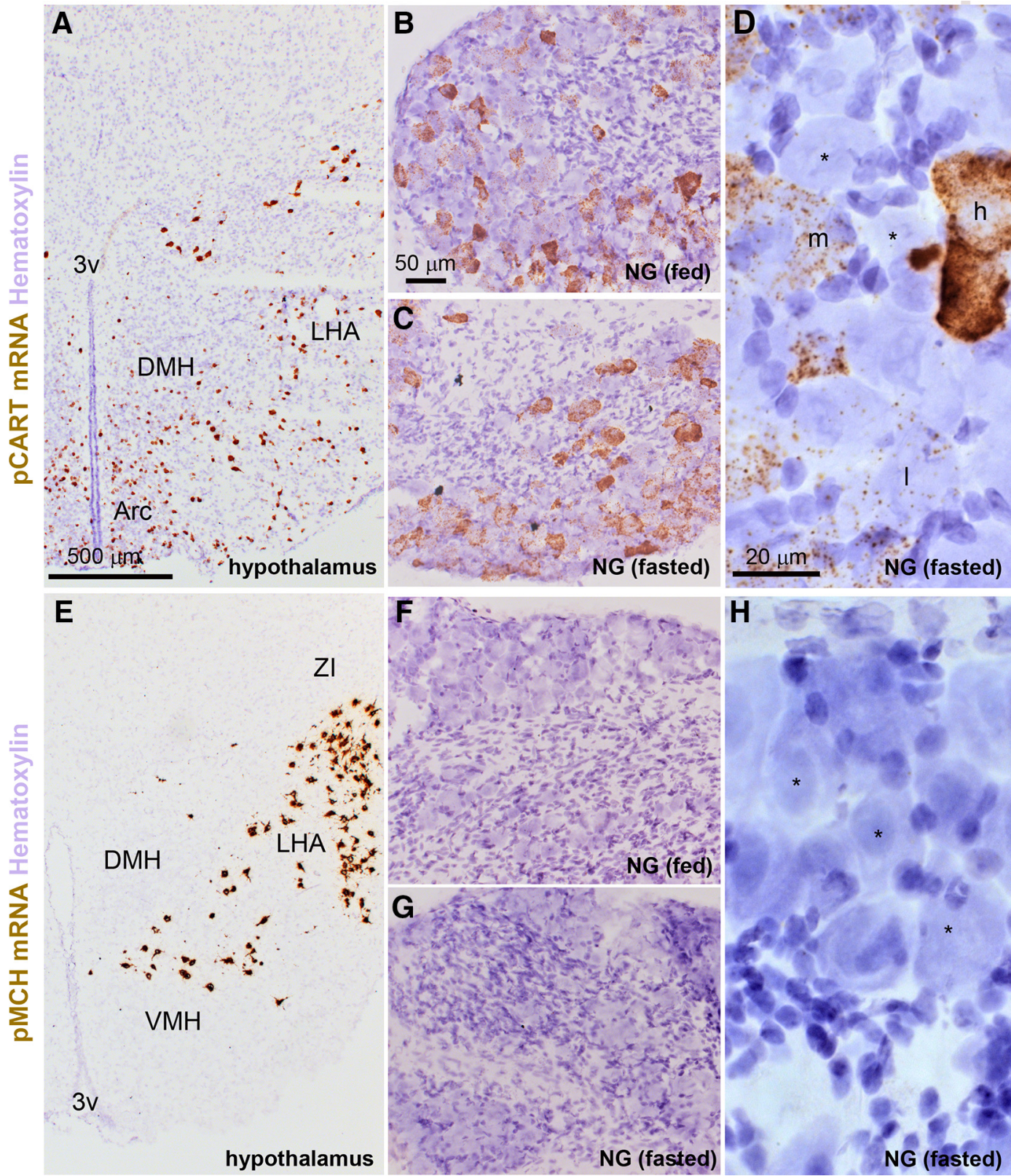

Figure 10. Detection of prepro-CART (pCART) and prepro-MCH $(\mathrm{pMCH}) \mathrm{mRNAs}$ using chromogenic ISH. $\boldsymbol{A}$, pCART hybridization signals (brown DAB; bright-field optics) were strong in select hypothalamic nuclei. $\boldsymbol{B}$, Throughout the nodose ganglion of fed mice, pCART signals of varying intensity were observed in many cell profiles. $\boldsymbol{C}$. The nodose ganglion of fasted mice also contained pCART hybridization signals. $\boldsymbol{D}$, Details of the hybridization signal in the nodose ganglion of one fasted mouse. Please note representative cell profiles without signal (*), or with low (l), medium (m), and high (h) signals. $\boldsymbol{E}$, Hybridization signals for $\mathrm{pMCH}$ were very strong in neurons of the lateral hypothalamus. $\boldsymbol{F}, \mathbf{G}$, In contrast to the hypothalamus, pMCH signals were not observed in the nodose ganglia of fed and fasted mice. $\boldsymbol{H}$, Details of the nodose ganglion of one fasted mouse showing several neuronal profiles completely devoid of signals (*). Tissue was counterstained with hematoxylin. 3V, third ventricle; Arc, arcuate nucleus; DMH, dorsomedial hypothalamus; LHA, lateral hypothalamus; NG, nodose ganglion; $\mathrm{VMH}$, ventromedial hypothalamus; ZI, zona incerta. Scale bars, $500 \mu \mathrm{m}$ in $\boldsymbol{A}$ and $\boldsymbol{E} ; 50 \mu \mathrm{m}$ in $\boldsymbol{B}, \boldsymbol{C}, \boldsymbol{F}$, and $\boldsymbol{G} ; 20 \mu \mathrm{m}$ in $\boldsymbol{D}$ and $\boldsymbol{H}$.

axons. However, CART did not colocalize with YFPlabeled axons themselves. For instance, ChR2-YFP-labeled specialized endings resembling vagal intraganglionic laminar endings were CART negative (Fig. 12B). Similar observations were reported in the duodenal mucosa (not shown). This suggested that CART is not efficiently transported to the peripheral sensory endings of C-fibers, including those in the vagus nerve.

\section{Discussion}

The present study characterized CART(55-102) immunoreactivity in the vagal afferents of $\mathrm{Na}_{v} 1.8-\mathrm{Cre}-\mathrm{ChR} 2-$ YFP mice. Our results indicated that CART(55-102) is constitutively expressed in approximately $55 \%$ of vagal $\mathrm{Na}_{v} 1.8$-expressing neurons, even in fasted mice. $\mathrm{MCH}$, a peptide that was previously reported to be induced in 

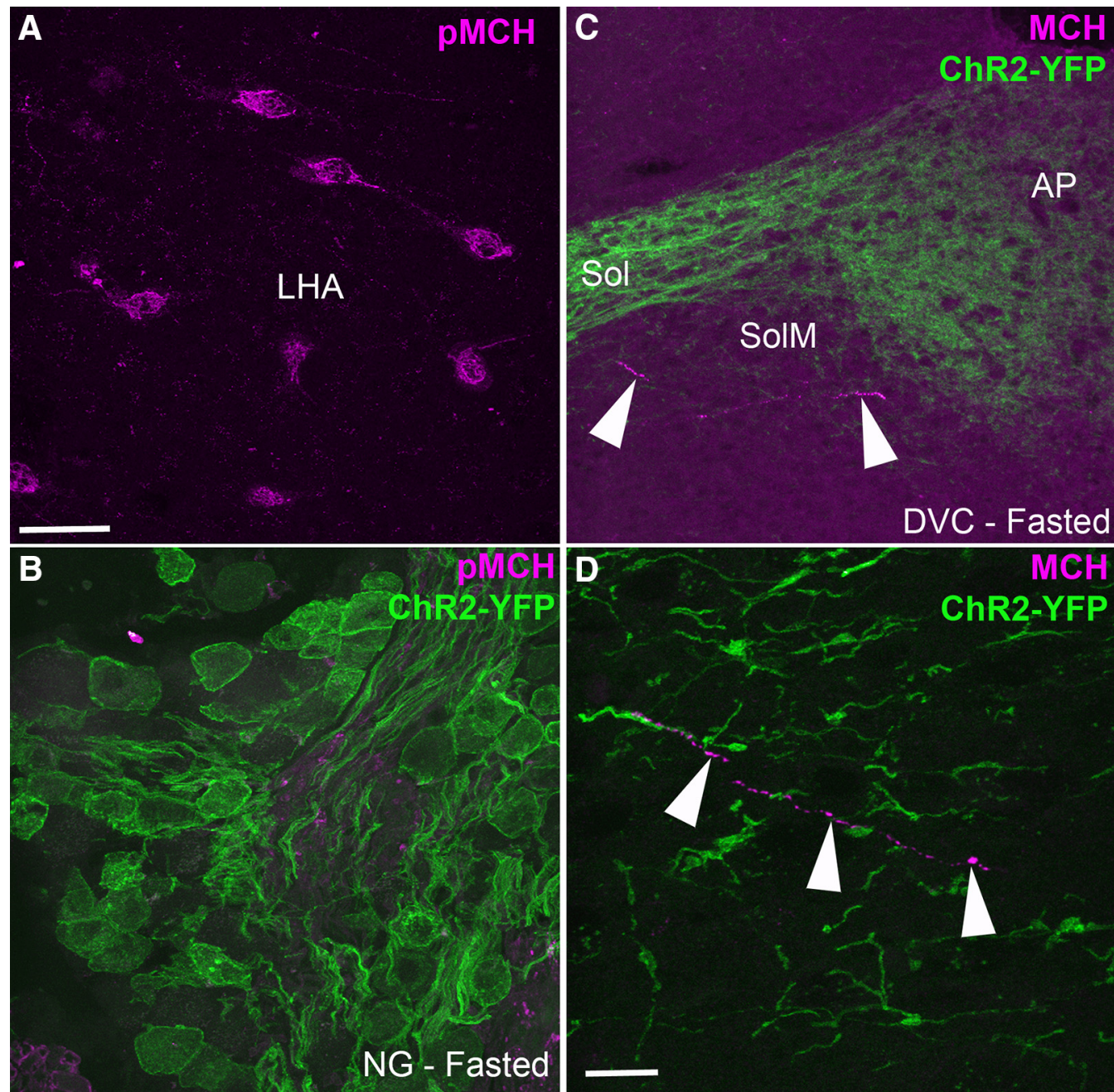

Figure 11. Absence of $\mathrm{MCH}$ staining in the vagal afferents of metabolically challenged $\mathrm{Na}_{\mathrm{v}} 1.8-\mathrm{Cre}-\mathrm{ChR} 2-\mathrm{YFP}$ mice. $\boldsymbol{A}$, An antiserum against prepro- $\mathrm{MCH}(\mathrm{pMCH})$ labeled perikarya (Alexa Fluor 594) in the lateral hypothalamus (LHA). $\boldsymbol{B}$, PMCH was undetectable in the nodose ganglion (NG) of fasted $\mathrm{Na}_{\mathrm{v}}$ 1.8-Cre-ChR2-YFP mice. $\boldsymbol{C}, \boldsymbol{D}$, An antiserum against the $\mathrm{MCH}$ peptide labeled very few axons (arrowhead) in the medial NTS (SoIM). MCH immunoreactivity was never observed in the YFP-labeled fibers of vagal origin. Arrowheads point to one $\mathrm{MCH}$-positive axon. sol, solitary tract. Scale bars, $40 \mu \mathrm{m}$ in $\boldsymbol{A}$ and $\boldsymbol{B} ; 10 \mu \mathrm{m}$ in $\boldsymbol{C}$.

CART-positive vagal afferents of fasted animals, was undetectable. In contrast to several studies, we concluded that the neuropeptidergic profile of the CART-positive vagal afferents is remarkably stable across the energy balance spectrum.

\section{Technical considerations}

We used reporter mice that invariably express ChR2YFP in $\mathrm{Na}_{v} 1.8-\mathrm{Cre}$-expressing cells to label C-fibers in their entirety. $\mathrm{Na}_{v} 1.8-\mathrm{Cre}$ mice crossed with either tdTomato or ChR2 reporter animals have previously been used to label the perikarya and axons of C-fibers, including somatosensory nociceptors (Gautron et al., 2011; Shields et al., 2012; Daou et al., 2013; Bonin et al., 2016). To our knowledge, this is the first study to use $\mathrm{Na}_{\mathrm{v}} 1$.8-Cre-ChR2YFP mice to describe visceral $\mathrm{C}$-fibers. Overall, our data further validate the usefulness of ChR2-YFP as an excellent neuronal tracer. In particular, ChR2-YFP presented the advantage of brightly labeling the membrane of both central and peripheral endings, thereby allowing the tracing of specialized endings at high resolution. In the dorsovagal complex, this approach was critical for distinguishing the axons of vagal origins from central axons. A minor caveat of this mouse model is that GFP immunohistochemistry was required to detect ChR2-YFP in peripheral tissues, probably because of its limited peripheral transport. In the past, isolectin B4 binding to C-fiber neurons has been commonly used to trace the perikarya and central axons of C-fiber neurons (Fang et al., 2006; Fullmer et al., 2007; Solorzano et al., 2015). However, because of extraneuronal binding (Kirkeby and Moe, 2001), isolectin B4 does not permit the labeling of axons that innervate peripheral tissues. In addition, numerous developmental, biological, and inflammatory factors influence isolectin B4 binding to sensory neurons (Beland and Fitzgerald, 2001; Fullmer et al., 2007); Therefore, it is possible that isolectin B4 binding to $\mathrm{C}$-fibers may vary in response to different physiological conditions.

In contrast to several previous studies (de Lartigue et al., 2007, 2010,2014), we did not observe any suppres- 

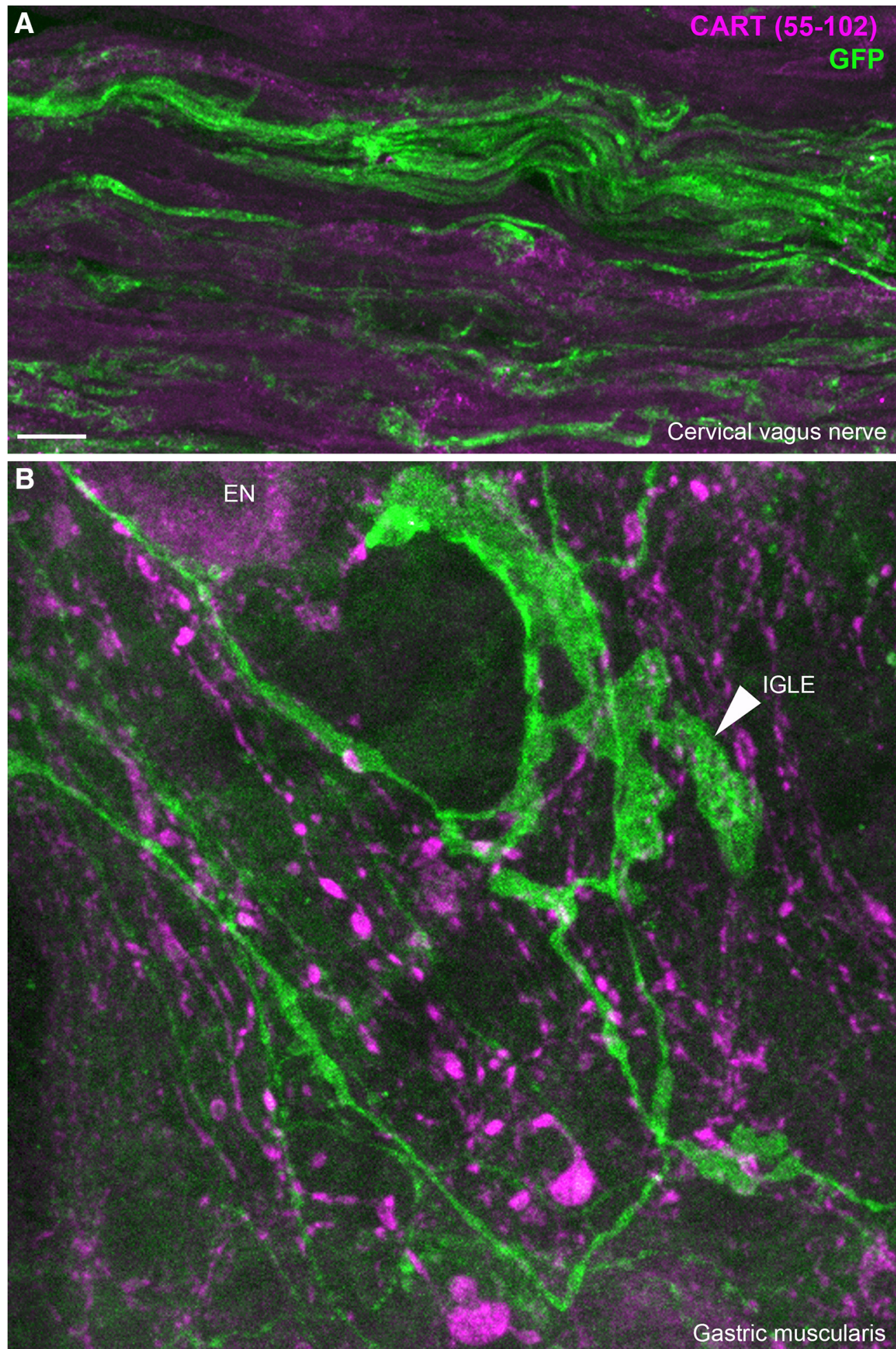

Figure 12. CART(55-102) immunolabeling of peripheral ChR2-YFP-labeled fibers. A, ChR2-YFP fibers contained within the cervical vagus nerve. CART was not detected in the vagus nerve. We obtained similar results in the cervical and subdiaphragmatic nerves on both sides. $\boldsymbol{B}$, In whole mounts of the gastric muscularis, numerous GFP-positive axons and specialized endings can be observed. The leafy structure may correspond to an intraganglionic laminar ending (arrowhead) of vagal origin. CART immunoreactivity was abundant in large varicose fibers and, to a lesser extent, the cell body of enteric neurons (EN). Nonetheless, CART immunoreactivity was not found in GFP-stained fibers. IGLE, intraganglionic laminar ending; EN, enteric neuron. Scale bar, $10 \mu \mathrm{m}$ in $\boldsymbol{A}$ and $\boldsymbol{B}$. 
sion of CART immunoreactivity in response to fasting, even though we used the same antibodies. However, our mouse data are in agreement with our ISH and the results of Broberger et al. (1999), who investigated the regulation of CART mRNA in metabolically challenged rats. Importantly, the number and appearance of CART-labeled cells were consistent with the published literature (Broberger et al., 1999; Zheng et al., 2002; Scruggs et al., 2003). In addition, abundant CART immunoreactivity was observed in the nodose ganglion of fasted rats. Together, these observations made us confident that the CART immunostaining observed in our study, including in the fasted mice, was not the result of false-positive labeling. Likewise, our failure to detect $\mathrm{MCH}$ in the nodose ganglion was not likely due to false-negative results because we used well-characterized antisera that successfully stained the brain. If $\mathrm{MCH}$ had been truly produced in the nodose ganglion of fasted animals, then we should have been able to detect it in the vagal terminals of the dorsovagal complex. More importantly, prepro-MCH mRNA was completely undetectable in the mouse nodose ganglion, even in the fasted condition. The absence of $\mathrm{MCH}$ in vagal afferents is consistent with the fact that the administration of $\mathrm{MCH}$ in the fourth ventricle does not influence food intake (Zheng et al., 2005; Baird et al., 2008). Even though differences in age, strain, bleeds of antibody, and diets may have influenced our results, we are confident that $\mathrm{MCH}$ is not produced by the vagal afferents.

\section{Neuropeptidergic makeup of the vagal afferents}

Although many different neuropeptides have been described in vagal afferents, the majority of them are expressed at relatively low levels or in small numbers of neurons, which is true for substance $P$, galanin, neuropeptide $\mathrm{Y}$, and calcitonin gene-related peptide (CGRP; Helke and Niederer, 1990; Calingasan and Ritter, 1992; Kummer et al., 1993; Matsumoto et al., 2003; Young et al., 2008). Of note, the aforementioned peptides are often produced by vagal afferents innervating the lungs (Undem et al., 2004; Plato et al., 2006) and therefore are not necessarily involved in feeding regulation. This contrasts sharply with CART, which is abundantly expressed in many vagal afferents, including those involved in feeding. Furthermore, our results indicate that CART expression in the nodose ganglion is not influenced by metabolic challenges. This result is not entirely surprising, because few physiological or pathophysiological stimuli have been reported to modify neuropeptide expression in vagal afferents, with the notable exception of the peripheral axotomy (Zhang et al., 1996; Reimer and Kanje, 1999). Hence, the neuropeptidergic profiles of the CART-positive hypothalamic neurons and CART-positive vagal afferents are substantially different. For instance, hypothalamic CART neurons often coexpress several feeding-related peptides (Elias et al., 1998). Moreover, hypothalamic CART expression is significantly altered by metabolic challenges, including food restriction (Kristensen et al., 1998) and highfat-diet feeding (Lee et al., 2013). Nonetheless, even in the hypothalamus, we are not aware of neurons switching from being anorectic to being orexigenic.
Most published studies agree that approximately $40-$ $50 \%$ of neurons are immunoreactive for CART in rats and mice in the fed condition (Zheng et al., 2002; de Lartigue et al., 2007; Gautron et al., 2012). Using radioactive ISH, approximately $48 \%$ of vagal afferents were found to express CART in the rat (Broberger et al., 1999). However, using chromogenic $\mathrm{ISH}$, we found that approximately $67 \%$ of the mouse vagal afferents expressed CART. This is likely because the RNAscope technology is not only more sensitive than immunofluorescence but also provides a better signal-to-noise ratio than radioactive ISH (Wang et al., 2012). Nonetheless, species differences in the distribution and percentage of vagal afferents expressing neuropeptides have been reported in the nodose ganglion of rats and mice (Zhuo et al., 1997). Therefore, we cannot completely rule out that CART mRNA is expressed in more vagal afferents in the mouse than in the rat. However, our current data in both species combined with that of Broberger et al. (1999) support the view that vagal CART is not regulated by fasting.

\section{Localization of CART in vagal terminals}

Many neuropeptides, including vasoactive intestinal peptide and CGRP, are known to be transported from the cell body of vagal afferents to their peripheral terminals (Zhuo et al., 1995). We expected to find CART in C-fiber terminals located in the stomach and duodenum, because previous studies clearly showed that CART-positive vagal afferents project to these locations (Zheng et al., 2002). Surprisingly, we failed to detect CART immunoreactivity in the axons and peripheral endings of vagal neurons that innervate the stomach wall and duodenal mucosa. We concluded that CART was not efficiently transported to the vagal endings and, consequently, may serve mainly as a central neurotransmitter. However, we cannot entirely rule out that our study missed CART immunoreactivity in the gastrointestinal tract. Further tracing studies are therefore warranted to determine the projection sites of CART-positive vagal afferents in both thoracic and abdominal viscera.

\section{References}

Aja S, Robinson BM, Mills KJ, Ladenheim EE, Moran TH (2002) Fourth ventricular CART reduces food and water intake and produces a conditioned taste aversion in rats. Behav Neurosci 116: 918-921. Medline

Baird JP, Rios C, Loveland JL, Beck J, Tran A, Mahoney CE (2008) Effects of hindbrain melanin-concentrating hormone and neuropeptide $\mathrm{Y}$ administration on licking for water, saccharin, and sucrose solutions. Am J Physiol Regul Integr Comp Physiol 294: R329-R343. CrossRef Medline

Beland B, Fitzgerald M (2001) Influence of peripheral inflammation on the postnatal maturation of primary sensory neuron phenotype in rats. J Pain 2:36-45. CrossRef

Biezonski DK, Trifilieff P, Meszaros J, Javitch JA, Kellendonk C (2015) Evidence for limited D1 and D2 receptor coexpression and colocalization within the dorsal striatum of the neonatal mouse. $J$ Comp Neur 523:1175-1189. CrossRef Medline

Bonin RP, Wang F, Desrochers-Couture M, Ga Secka A, Boulanger ME, Côté DC, De Koninck Y (2016) Epidural optogenetics for controlled analgesia. Mol Pain 12:CrossRef Medline

Broberger C, Holmberg K, Kuhar MJ, Hökfelt T (1999) Cocaine- and amphetamine-regulated transcript in the rat vagus nerve: a puta- 
tive mediator of cholecystokinin-induced satiety. Proc Natl Acad Sci U S A 96:13506-13511. Medline

Burdyga G, Varro A, Dimaline R, Thompson DG, Dockray GJ (2006) Feeding-dependent depression of melanin-concentrating hormone and melanin-concentrating hormone receptor-1 expression in vagal afferent neurones. Neuroscience 137:1405-1415. CrossRef Medline

Calingasan NY, Ritter S (1992) Presence of galanin in rat vagal sensory neurons: evidence from immunohistochemistry and in situ hybridization. J Auton Nerv Syst 40:229-238. Medline

Calupca MA, Locknar SA, Zhang L, Harrison TA, Hoover DB, Parsons $R L$ (2001) Distribution of cocaine- and amphetamine-regulated transcript peptide in the guinea pig intrinsic cardiac nervous system and colocalization with neuropeptides or transmitter synthetic enzymes. J Comp Neur 439:73-86. CrossRef Medline

Chiu IM, Barrett LB, Williams EK, Strochlic DE, Lee S, Weyer AD, Lou S, Bryman GS, Roberson DP, Ghasemlou N, Piccoli C, Ahat E, Wang V, Cobos EJ, Stucky CL, Ma Q, Liberles SD, Woolf CJ (2014) Transcriptional profiling at whole population and single cell levels reveals somatosensory neuron molecular diversity. eLife 3:CrossRef Medline

Cork SC, Richards JE, Holt MK, Gribble FM, Reimann F, Trapp S (2015) Distribution and characterisation of glucagon-like peptide-1 receptor expressing cells in the mouse brain. Mol Metab 4:718731. CrossRef Medline

Croizier S, Franchi-Bernard G, Colard C, Poncet F, La Roche A, Risold PY (2010) A comparative analysis shows morphofunctional differences between the rat and mouse melanin-concentrating hormone systems. PloS One 5:e15471CrossRef Medline

Daou I, Tuttle AH, Longo G, Wieskopf JS, Bonin RP, Ase AR, Wood JN, De Koninck Y, Ribeiro-da-Silva A, Mogil JS, Séguéla P (2013) Remote optogenetic activation and sensitization of pain pathways in freely moving mice. J Neurosci 33:18631-18640. CrossRef Medline

de La Serre CB, de Lartigue G, Raybould HE (2015) Chronic exposure to low dose bacterial lipopolysaccharide inhibits leptin signaling in vagal afferent neurons. Physiol Behav 139:188-194. CrossRef Medline

de Lartigue G, Dimaline R, Varro A, Dockray GJ (2007) Cocaine- and amphetamine-regulated transcript: stimulation of expression in rat vagal afferent neurons by cholecystokinin and suppression by ghrelin. J Neurosci 27:2876-2882. CrossRef Medline

De Lartigue G, Dimaline R, Varro A, Raybould H, De la Serre CB, Dockray GJ (2010) Cocaine- and amphetamine-regulated transcript mediates the actions of cholecystokinin on rat vagal afferent neurons. Gastroenterology 138:1479-1490. CrossRef Medline

de Lartigue G, Ronveaux CC, Raybould HE (2014) Deletion of leptin signaling in vagal afferent neurons results in hyperphagia and obesity. Mol Metab 3:595-607. CrossRef Medline

Deurveilher S, Lo H, Murphy JA, Burns J, Semba K (2006) Differential c-Fos immunoreactivity in arousal-promoting cell groups following systemic administration of caffeine in rats. J Comp Neur 498:667689. CrossRef Medline

Dun NJ, Dun SL, Wong PY, Yang J, Chang J (2000) Cocaine- and amphetamine-regulated transcript peptide in the rat epididymis: an immunohistochemical and electrophysiological study. Biol Reprod 63:1518-1524. Medline

Ekblad E, Kuhar M, Wierup N, Sundler F (2003) Cocaine- and amphetamine-regulated transcript: distribution and function in rat gastrointestinal tract. Neurogastroenterol Motil 15:545-557. Medline

Elias CF, Lee C, Kelly J, Aschkenasi C, Ahima RS, Couceyro PR, Kuhar MJ, Saper CB, Elmquist JK (1998) Leptin activates hypothalamic CART neurons projecting to the spinal cord. Neuron 21:1375-1385. Medline

Fang X, Djouhri L, Black JA, Dib-Hajj SD, Waxman SG, Lawson SN (2002) The presence and role of the tetrodotoxin-resistant sodium channel $\mathrm{Na}(\mathrm{v}) 1.9(\mathrm{NaN})$ in nociceptive primary afferent neurons. J Neurosci 22:7425-7433. Medline
Fang X, Djouhri L, McMullan S, Berry C, Waxman SG, Okuse K, Lawson SN (2006) Intense isolectin-B4 binding in rat dorsal root ganglion neurons distinguishes C-fiber nociceptors with broad action potentials and high Nav1.9 expression. J Neurosci 26:72817292. CrossRef Medline

Fullmer JM, Riedl M, Williams FG, Sandrin M, Elde R (2007) Enzymes that synthesize the IB4 epitope are not sufficient to impart IB4 binding in dorsal root ganglia of rat. J Comp Neur 501:70-82. CrossRef Medline

García-Pérez D, Sáez-Belmonte F, Laorden ML, Núñez C, Milanés MV (2013) Morphine administration modulates expression of Argonaute 2 and dopamine-related transcription factors involved in midbrain dopaminergic neurons function. $\mathrm{Br} \mathrm{J}$ Pharmacol 168: 1889-1901. CrossRef Medline

Gautron L, Lee CE, Lee S, Elmquist JK (2012) Melanocortin-4 receptor expression in different classes of spinal and vagal primary afferent neurons in the mouse. J Comp Neur 520:3933-3948. CrossRef Medline

Gautron L, Sakata I, Udit S, Zigman JM, Wood JN, Elmquist JK (2011) Genetic tracing of Nav1.8-expressing vagal afferents in the mouse. J Comp Neur 519:3085-3101. CrossRef Medline

Glavas MM, Grayson BE, Allen SE, Copp DR, Smith MS, Cowley MA, Grove KL (2008) Characterization of brainstem peptide YY (PYY) neurons. J Comp Neur 506:194-210. CrossRef Medline

Gonsalvez DG, Kerman IA, McAllen RM, Anderson CR (2010) Chemical coding for cardiovascular sympathetic preganglionic neurons in rats. J Neurosci 30:11781-11791. CrossRef Medline

Gorham JD, Baker H, Kegler D, Ziff EB (1990) The expression of the neuronal intermediate filament protein peripherin in the rat embryo. Brain Res Dev Brain Res 57:235-248. Medline

Heldsinger A, Lu Y, Zhou SY, Wu X, Grabauskas G, Song I, Owyang C (2012) Cocaine- and amphetamine-regulated transcript is the neurotransmitter regulating the action of cholecystokinin and leptin on short-term satiety in rats. Am J Physiol Gastrointest Liver Physiol 303:G1042-G1051. CrossRef Medline

Helke CJ, Niederer AJ (1990) Studies on the coexistence of substance $\mathrm{P}$ with other putative transmitters in the nodose and petrosal ganglia. Synapse 5:144-151. CrossRef Medline

Jennings JH, Stuber GD (2014) Tools for resolving functional activity and connectivity within intact neural circuits. Curr Biol 24:R41R50. CrossRef Medline

Kirkeby S, Moe D (2001) Binding of Griffonia simplicifolia 1 isolectin B4 (GS1 B4) to alpha-galactose antigens. Immunol Cell Biol 79: 121-127. CrossRef Medline

Koylu EO, Couceyro PR, Lambert PD, Ling NC, DeSouza EB, Kuhar MJ (1997) Immunohistochemical localization of novel CART peptides in rat hypothalamus, pituitary and adrenal gland. J Neuroendocrinol 9:823-833. Medline

Kristensen P, Judge ME, Thim L, Ribel U, Christjansen KN, Wulff BS, Clausen JT, Jensen PB, Madsen OD, Vrang N, Larsen PJ, Hastrup $S$ (1998) Hypothalamic CART is a new anorectic peptide regulated by leptin. Nature 393:72-76. CrossRef Medline

Kummer W, Bachmann S, Neuhuber WL, Hänze J, Lang RE (1993) Tyrosine-hydroxylase-containing vagal afferent neurons in the rat nodose ganglion are independent from neuropeptide-Y-containing populations and project to esophagus and stomach. Cell Tissue Res 271:135-144. Medline

Lee SJ, Verma S, Simonds SE, Kirigiti MA, Kievit P, Lindsley SR, Loche A, Smith MS, Cowley MA, Grove KL (2013) Leptin stimulates neuropeptide $Y$ and cocaine amphetamine-regulated transcript coexpressing neuronal activity in the dorsomedial hypothalamus in diet-induced obese mice. J Neurosci 33:1530615317. CrossRef Medline

Madisen L, Zwingman TA, Sunkin SM, Oh SW, Zariwala HA, Gu H, $\mathrm{Ng}$ LL, Palmiter RD, Hawrylycz MJ, Jones AR, Lein ES, Zeng H (2010) A robust and high-throughput Cre reporting and characterization system for the whole mouse brain. Nat Neurosci 13:133140. CrossRef Medline

Marques-Lopes J, Van Kempen T, Waters EM, Pickel VM, ladecola C, Milner TA (2014) Slow-pressor angiotensin II hypertension and 
concomitant dendritic NMDA receptor trafficking in estrogen receptor beta-containing neurons of the mouse hypothalamic paraventricular nucleus are sex and age dependent. J Comp Neur 522:3075-3090. CrossRef Medline

Matsumoto I, Emori Y, Nakamura S, Shimizu K, Arai S, Abe K (2003) DNA microarray cluster analysis reveals tissue similarity and potential neuron-specific genes expressed in cranial sensory ganglia. J Neurosci Res 74:818-828. CrossRef Medline

Muñoz W, Tremblay R, Rudy B (2014) Channelrhodopsin-assisted patching: in vivo recording of genetically and morphologically identified neurons throughout the brain. Cell Rep 9:2304-2316. CrossRef Medline

Plato M, Kummer W, Haberberger RV (2006) Structural and neurochemical comparison of vagal and spinal afferent neurons projecting to the rat lung. Neurosci Lett 395:215-219. CrossRef Medline

Reeber SL, Sillitoe RV (2011) Patterned expression of a cocaine- and amphetamine-regulated transcript peptide reveals complex circuit topography in the rodent cerebellar cortex. J Comp Neur 519: 1781-1796. CrossRef Medline

Reimer M, Kanje M (1999) Peripheral but not central axotomy promotes axonal outgrowth and induces alterations in neuropeptide synthesis in the nodose ganglion of the rat. Eur $\mathrm{J}$ Neurosci 11: 3415-3423. CrossRef

Rogge G, Jones D, Hubert GW, Lin Y, Kuhar MJ (2008) CART peptides: regulators of body weight, reward and other functions. Nat Rev Neurosci 9:747-758. CrossRef Medline

Scruggs P, Dun SL, Dun NJ (2003) Cocaine- and amphetamineregulated transcript peptide attenuates phenylephrine-induced bradycardia in anesthetized rats. Am J Physiol Regul Integr Comp Physiol 285:R1496-R1503. CrossRef Medline

Shields SD, Ahn HS, Yang Y, Han C, Seal RP, Wood JN, Waxman SG, Dib-Hajj SD (2012) $\mathrm{Na}(\mathrm{v}) 1.8$ expression is not restricted to nociceptors in mouse peripheral nervous system. Pain 153:20172030. CrossRef Medline

Solorzano C, Villafuerte D, Meda K, Cevikbas F, Bráz J, Sharif-Naeini R, Juarez-Salinas D, Llewellyn-Smith IJ, Guan Z, Basbaum AI (2015) Primary afferent and spinal cord expression of gastrinreleasing peptide: message, protein, and antibody concerns. $J$ Neurosci 35:648-657. CrossRef Medline

Stanley SA, Small CJ, Murphy KG, Rayes E, Abbott CR, Seal LJ, Morgan DG, Sunter D, Dakin CL, Kim MS, Hunter R, Kuhar M, Ghatei MA, Bloom SR (2001) Actions of cocaine- and amphetamine-regulated transcript (CART) peptide on regulation of appetite and hypothalamo-pituitary axes in vitro and in vivo in male rats. Brain Res 893:186-194. Medline

Stirling LC, Forlani G, Baker MD, Wood JN, Matthews EA, Dickenson AH, Nassar MA (2005) Nociceptor-specific gene deletion using heterozygous NaV1.8-Cre recombinase mice. Pain 113:27-36. CrossRef Medline

Thim L, Kristensen P, Nielsen PF, Wulff BS, Clausen JT (1999) Tissue-specific processing of cocaine- and amphetamineregulated transcript peptides in the rat. Proc Natl Acad Sci U S A 96:2722-2727. Medline

Tseng KW, Chau YP, Yang MF, Lu KS, Chien CL (2008) Abnormal cellular translocation of alpha-internexin in spinal motor neurons of Dystonia musculorum mice. J Comp Neur 507:1053-1064. CrossRef Medline
Undem BJ, Chuaychoo B, Lee MG, Weinreich D, Myers AC, Kollarik M (2004) Subtypes of vagal afferent C-fibres in guinea-pig lungs. J Physiol 556:905-917. CrossRef Medline

Usoskin D, Furlan A, Islam S, Abdo H, Lönnerberg P, Lou D, HjerlingLeffler J, Haeggström J, Kharchenko O, Kharchenko PV, Linnarsson S, Ernfors P (2015) Unbiased classification of sensory neuron types by large-scale single-cell RNA sequencing. Nat Neurosci 18:145-153. CrossRef Medline

Valera AG, Cavalcante JC, Elias CF, Felício LF (2006) Cocaine- and amphetamine-regulated transcript is overexpressed in the anteroventral periventricular nucleus of pregnant rats. J Neuroendocrinol 18:711-714. CrossRef Medline

Volkmann K, Chen YY, Harris MP, Wullimann MF, Koster RW (2010) The zebrafish cerebellar upper rhombic lip generates tegmental hindbrain nuclei by long-distance migration in an evolutionary conserved manner. J Comp Neur 518:2794-2817.

Wang F, Flanagan J, Su N, Wang LC, Bui S, Nielson A, Wu X, Vo HT, Ma XJ, Luo Y (2012) RNAscope: a novel in situ RNA analysis platform for formalin-fixed, paraffin-embedded tissues. J Mol Diagn 14:22-29. CrossRef Medline

Whiddon BB, Palmiter RD (2013) Ablation of neurons expressing melanin-concentrating hormone $(\mathrm{MCH})$ in adult mice improves glucose tolerance independent of $\mathrm{MCH}$ signaling. J Neurosci 33: 2009-2016. CrossRef Medline

Xiao S, Tjostheim S, Sanelli T, McLean JR, Horne P, Fan Y, Ravits J, Strong MJ, Robertson J (2008) An aggregate-inducing peripherin isoform generated through intron retention is upregulated in amyotrophic lateral sclerosis and associated with disease pathology. $J$ Neurosci 28:1833-1840. CrossRef Medline

Yi F, Catudio-Garrett E, Gábriel R, Wilhelm M, Erdelyi F, Szabo G, Deisseroth K, Lawrence J (2015) Hippocampal "cholinergic interneurons" visualized with the choline acetyltransferase promoter: anatomical distribution, intrinsic membrane properties, neurochemical characteristics, and capacity for cholinergic modulation. Front Synaptic Neurosci 7:4CrossRef Medline

Young RL, Cooper NJ, Blackshaw LA (2008) Chemical coding and central projections of gastric vagal afferent neurons. Neurogastroenterol Motil 20:708-718. CrossRef Medline

Zhang X, Ji RR, Arvidsson J, Lundberg JM, Bartfai T, Bedecs K, Hökfelt T (1996) Expression of peptides, nitric oxide synthase and NPY receptor in trigeminal and nodose ganglia after nerve lesions. Exp Brain Res 111:393-404. Medline

Zheng H, Patterson LM, Berthoud HR (2002) CART in the dorsal vagal complex: sources of immunoreactivity and effects on Fos expression and food intake. Brain Res 957:298-310. Medline

Zheng H, Patterson LM, Morrison C, Banfield BW, Randall JA, Browning KN, Travagli RA, Berthoud HR (2005) Melanin concentrating hormone innervation of caudal brainstem areas involved in gastrointestinal functions and energy balance. Neuroscience 135: 611-625. CrossRef Medline

Zhuo H, Ichikawa H, Helke CJ (1997) Neurochemistry of the nodose ganglion. Prog Neurobiol 52:79-107. Medline

Zhuo H, Lewin AC, Phillips ET, Sinclair CM, Helke CJ (1995) Inhibition of axoplasmic transport in the rat vagus nerve alters the numbers of neuropeptide and tyrosine hydroxylase messenger RNAcontaining and immunoreactive visceral afferent neurons of the nodose ganglion. Neuroscience 66:175-187. Medline 